
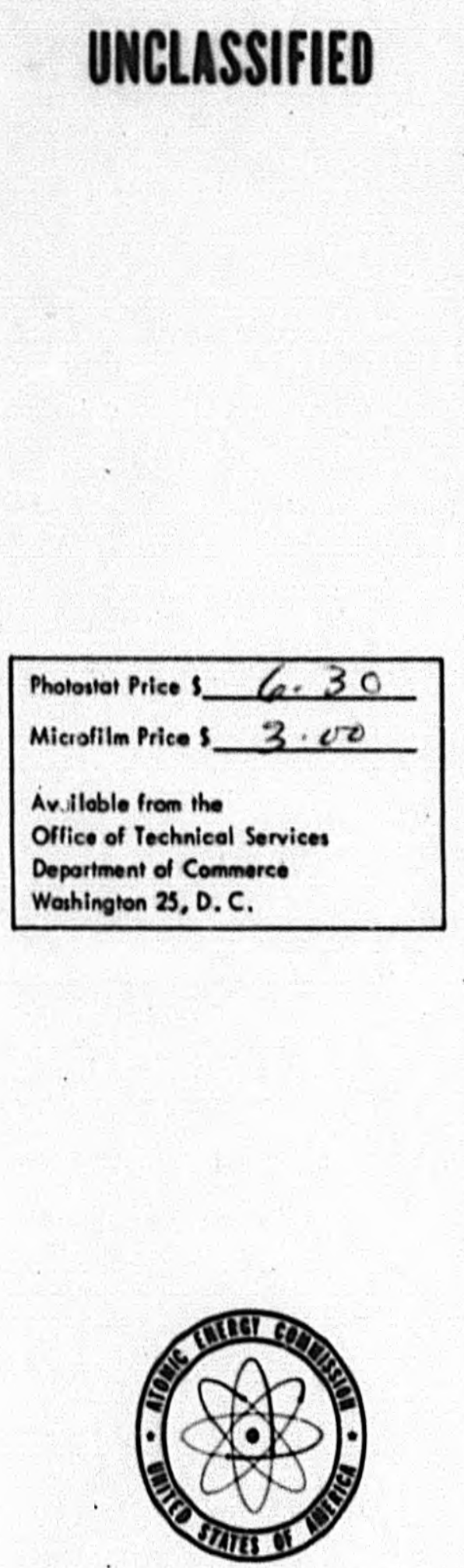

UNCLASSIFIED
AECD-4049

UNITED STATES ATOMIC ENERGY COMMISSION

THE PRODUCTION OF URANIUM METAL BY METAL HYDRIDES INCORPORATED

BY

P. P. Alexander

1943

Date Declassifiéd: January 12, 1956

Metal Hydrides, Inc.

Tochnical Information Sorvice, Ook Ridoe, Tennesser 


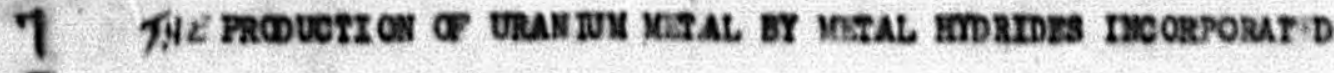

BY

\section{P. P. Aloxtuter}

Szropale

Wotal pydrides Inoorperated ans a ploeser in tho produot ea of urantua notal on a comerelal sealo and ouppled it to s1l the 2aberatorles tatereoted in the eris inal weearch, before other mothode fer 2to production were dovelopod.

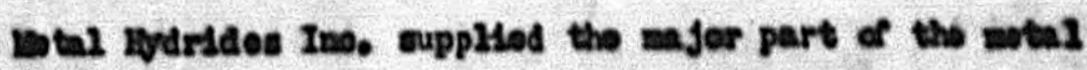

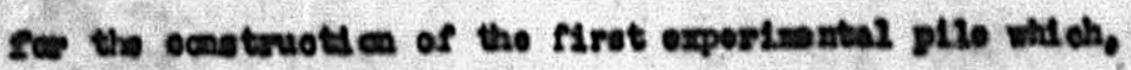

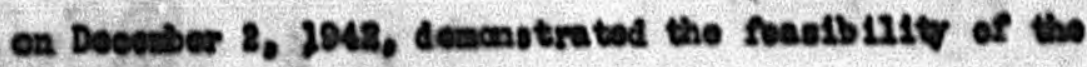
esle-gurtating chain reaction and the roleace of atondo enesco.

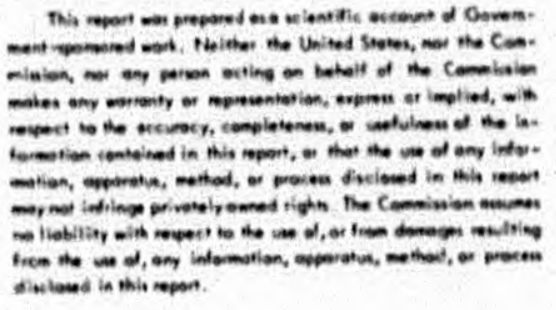




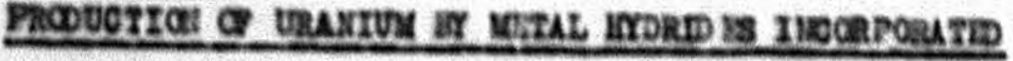

by

P. P. Aloxanter

\section{Orletnal Vork}

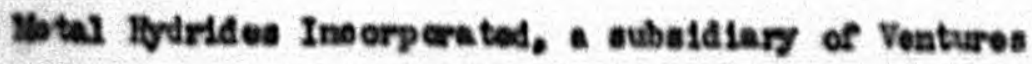
Linited, was a pleceer in the work on the production of uranI wa ch a comerelal oode. Thle pure motal and 1te alloge were produoed for use in various solentifio laboratories and by a for comsarelal eompantes.

Vraniun notal we produoed by the reduotion of black

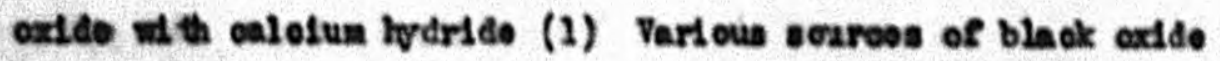
wove imeatigatod inolud fine oxido rron Camadn, the Bolgian Congo, and dosentio oxddes produesd froe coloredo ore purchased

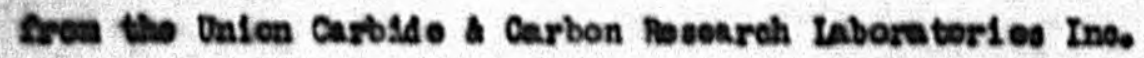
The pure watal was at flrot produced in tho from of pender (Pat I) which was rueod Into enall Ingote (PIa to II) In labor. atory veeuru furnaoos. The powdor wa ruaed at a terpopature as 20 as $1100^{\circ} \mathrm{C}$ and oven ecmowhat lower." At thes otage of devolopunt the uranlun motal we prodused in ene pound lots.

The produoti on of ocmerolally pure matal began on a

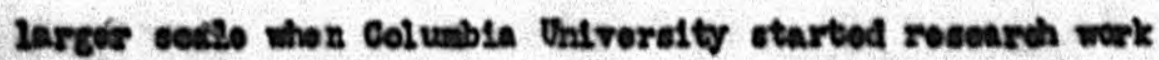
In tho veo of this motal, and placod thelr Arat edor for

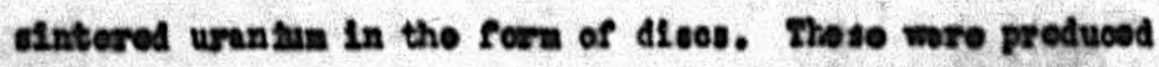

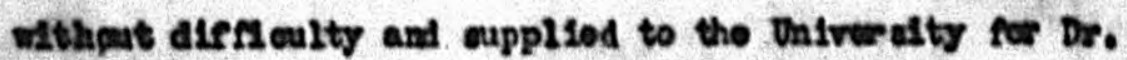
Peral 's and Dr. sellard 's work, Later tho conditlons of the oxperlenents wroro changed ond larger ancuuts wore noeded. Columila Valveresty thorofore placod ordere for uranitua notal In the rorn of perder whloh was ueod to 112 holler dises and

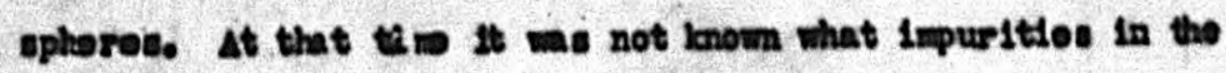




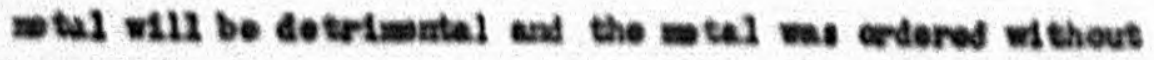
any opedfleatione of analyets, exoopt that the enount of

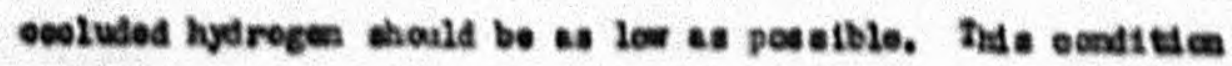
wa casily wet by degasing the poerdered motal at hl gh terper ature in veouns.

The seale of productl on was imoreaned. At that wrage urantua as produed in lote of twanty pound, in the tara of fine pewder.

In 2942 it becas ovident that otill larger quantl tion of thle notal would be noeded, and a oentreet ae placed to the Bureeu of standarda for wry much lar gor quants thes of coumereda lis pure notal la poudor roma.

II. Produotlon of lotal fron Canadian Black oodde

Do work we started on the frodivetsen of th is Inltial ordor for the bureau of standarda and som five himdrod pounda of natal was produoed by using the canedian bla ok oxide pur-

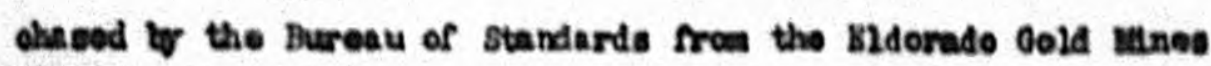
Linftod of canada.

In the mentim the solonts ats found that in adaitien to lyd rogon, wiother impurity, boron, was extrobuly dotrlnatal and that ite preesene in tho notal would provent then from obtaining the destred rooulta. It wa also found that the domertio ealelua produced ty the Union Carbide a carben cerpore atlon contained approciablo anounte of beros. It as fur the found that boros was also preseat in minuto guent! tlos in the Canadien bla ok exddo. It was doclded that before going axy further with the profuction of pure urantum notal, it would 
be weseary Flrat, to obtain esles un troe tron boron, and then to ake emransesents for the purifloatien of the canadian black oxide.

The tost sade by tr. Rodden of the Jureau of stundards

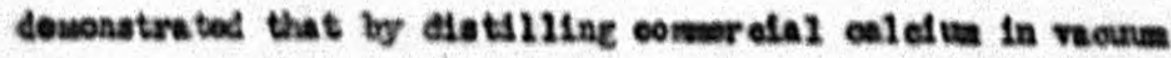
1t wa poesble to elininato preotsoalty all the bor on and 00 obtaln ealolus whioh would be entirely eatleferetery for weo at a roduoling roagent in the produotion of pure urantuna, with the halp of the berseas of Standarda the diotillation plant

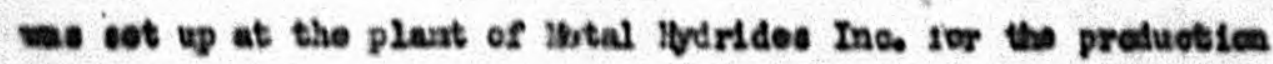
of alatillod oclolum motal on a comenerolal sealo. At Arat this operation prosented ocnsiderablo diffloultion alneo tho

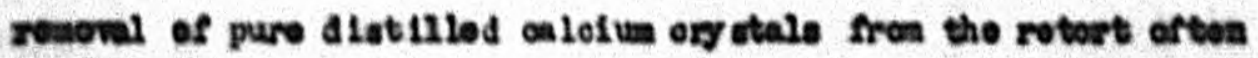
reculsed In fires.

latal bodrides Ino, horover sound that diatilled calolua could be oonverted Into oal of un hydirlde in tho ease operation. Thle elininatod additlonal expenes ant ooneldomablo canger in handing froehly diotillod oalol in. Tho produotien of diatiliod calotion hydrido was otarted at flret on a reduced sealo whoh

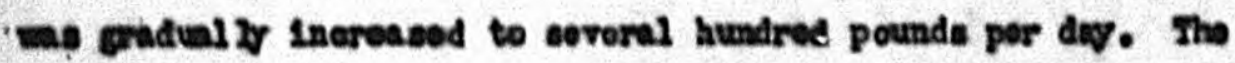
Aret enall lot of purlelod black ocdde from Canada we roduoed

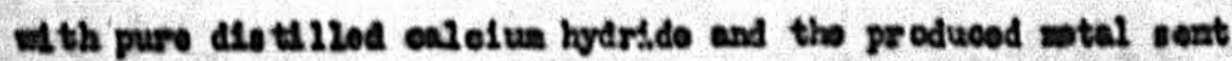
to the Bureau of standards fer analyale. It was roported by b. Iodeon thet the boren coutent was $20 s e$ than eno hals part

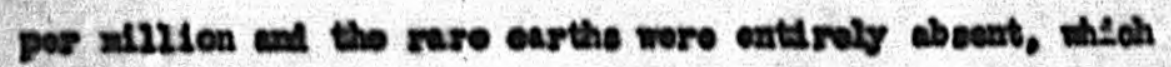
infleated thet by theeo meane it would be poesible to protuve 


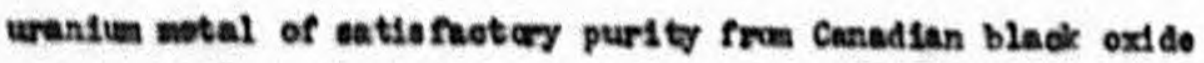
and diatillod oul ofum.

\section{Berinning of the Nork for 0.3.1.0.}

In the moantim the oclentl ste round that still largor quantitiles of mater bal would be nooded for thotr experisente. A contract wa nogotiatod, therefore, wh the orflee of selentiflo Rosearch and Developrent. It mas agreed that' in vlow of the unueval mature of this material, no analyeis would bo epeolified. In rot, at that atage of the work the sesentists thenaelvee did not know what purity of matal will be neceseary In ordor to achiove the dosired results.

The firat oontraet with the 0,8.R.D. expiring on Jums 80 . 2942, wa renotod to Norember 1, 1942. From that dato on tho production of ureniun by llotal ifydrides Ino, mas on diroot

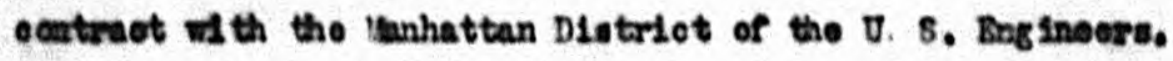
At that atage tho produoti on of uranium antal by Motal pydridos Ino. wis Inoreased to two hundred and sifty pounts per deve.

\section{Cagtins and Bintoring of llotal}

Tho original work of liotal pydrides Ins, denonotrated es earky es 1935 that ureniug pondor could bo mited very eace cesaruldy In vaouin at the oomparatifoly 20 temporaturo of 2200\% . (2) Tho wlting we oarriod on in enill laberatery

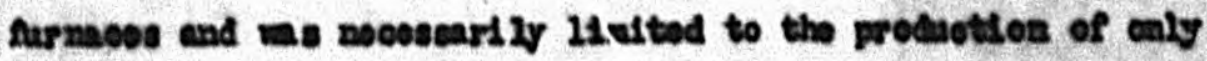
vary enll Ingote. Howover, an Invootigatica wae otarted to find a more sapld wthod of molting, and urenitu in powder resm we cont to soveral laborators os equipped with his frequang vaouva furmaces.

The firot reaste at tho Buroau of standarde and in the 


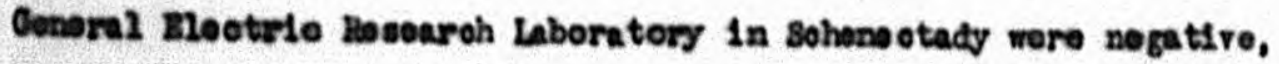
and opinione on the praotleablility of uaing tho high frequenoy w thod wore divided. Hotal Hydrides Ino. wnited to oonti nus the Imreats gation and find somo laboratory where the solting of urantua ponder in a hich troquanoy Rurnaco oould be tried out againg whereas other interosted partiles hold tho opinlon that the rusion should be mado in the resiotanoe heator type surnaces.

In the meanting samples of pooderod uranlum motal were abseltted by Votal Hydrides Inc, to the laseschusotts Inotituto of Iochnolog asd arrangeres nte wore sado at the Dopartiont of Uotallurey for Dr. J. Chipman to fues this motal in a hifh froe

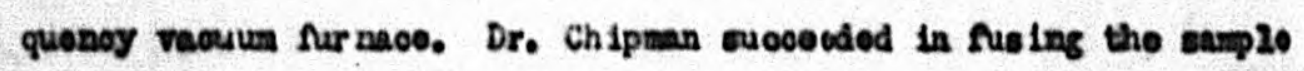
of notal Into a well-formad diso of $2^{\prime \prime}$ diamotor, by ualing a opoelal toohnio, namoly by placing the pondered motal in an alundune oruolblo whlch was surrcunded by a graphlto ohlold. (P2ato III)

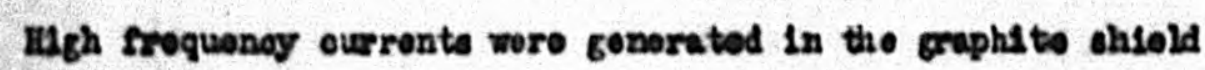
thloh wes guiakly brought up to a very high tenporaturo. Tho materlel in the cruclble wal thereforo hoatod and mitod, not by the high rreguency ourronts generated whin 1 to mass, but by rediation from tho Imoandoscont eraphlto ollold. The previous sallures by the sureau of standarde were duo to tho frot that attonpte wore medo to ruso pendored notal in arrebles

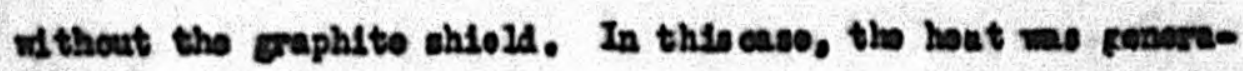
tod onity In 1eolatod partiloles of tho motal. It tolk too 2013 to bying tho pordored mes to a torporetere areflolentis high

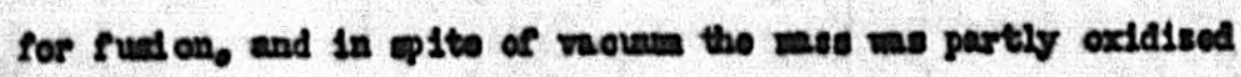
by the remining traces of alr borose the dealsed torperature mes reached. 
Arrangomants woro mado Imudiatoly botwoen lotal Bydridos Ino. and the laseschusotts Institute of Toohnology. Motal Eydrides Ine. Aarnishod a more offlolent and larger oapaolts vaouna puep and sade a suboontraot of th tho vaceachusotta Insta tuto of Tochnolog providing the nocoseary rud to procoed with the work withent dolay.

In the pantine motel ror the initilal exporinents in Chicago Was neoded so urgontiv that it wa doolded teaporarily to ues enother expedient of consolidating pondered notal into omall solsd b11lote. Tho alntering of the pondor wich was suecosafuly earried on ty Watal Eydrides Ino. In the produotion of the first eolid dieos

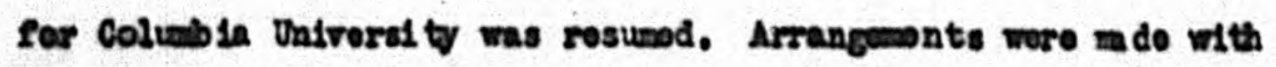
tho laseachusetto Institurto of Tochnol $0 \mathrm{~g}$ to get a largor hrdraulso proes for proseing the poudered motal at 70 tons por equare inch

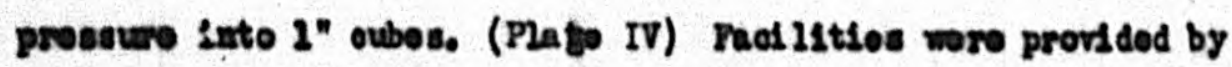
the Inoeachusetts Instituto of Tochnolog and the work was otartod.

The urentue ponder produoed of Notal Evdrides Ine. In Beverly

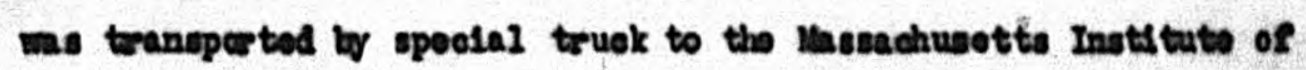
Toolanolog and proasod Into cubes wh10h waro tranopertod baok to Evtal Evirides Ino. In Boverly whore thoy wore sintered Into solid blocke. Th donalty goolfled by the Ghieago Group wa not 1080 than 26, and the flrot scries of prossed oubes after ointoring woro of oven hichor donglty, in como casos reaching 17. Thovo

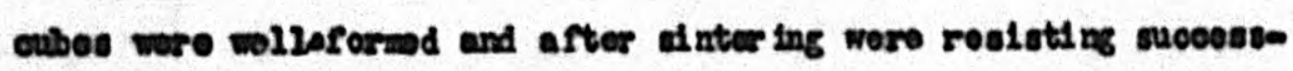

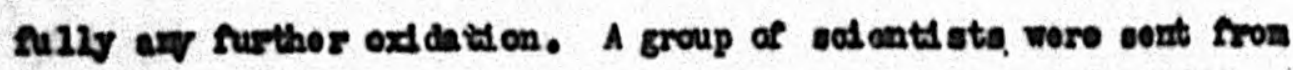
Chicago and the work of proasing at the Masaohusetts Inoth tute of geohnoleg wal creandiced on a very mach lar gor scalo. Faollitios were provided to prese up to several humdred parnls o: oubos per deg which on tho Sollowing day wore transported back to Bowerky 
and olntered lito oolid blooke.

At that tise, howover, listal pydrides Ins. wes reque otod

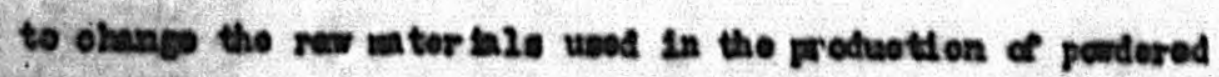
trantun, and Instead of blask oxddo, to uso exolus ivoly brown aloxde.

The dange of rear mter la 18 ereatod lemodiatoly now problome.

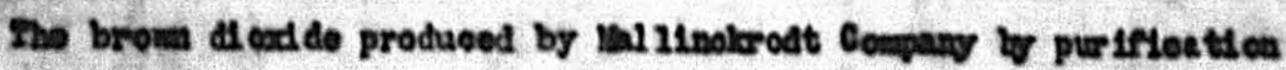
end pertial recuotlon of the bleck oxddo, 10 a prrophorlo atter 1al

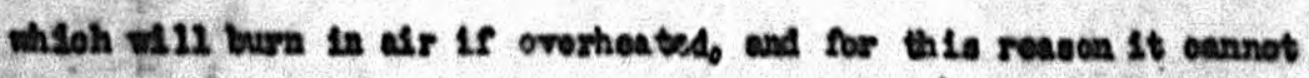

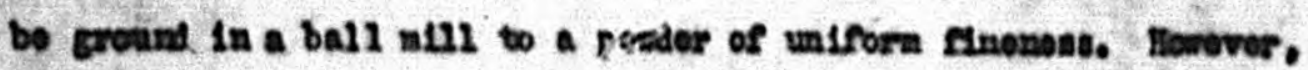
at nee the purity of the brown dioxdde is ereater than that of the cousnorolas black oxddo, It was doolded to use It in all frother work.

The phroieal structure of the exides is quite differente Fis bleok oxd de conalute of very fin solld partialos, It oan bo ground In a ball nill If nocoosary to sarthor reduce it to ang

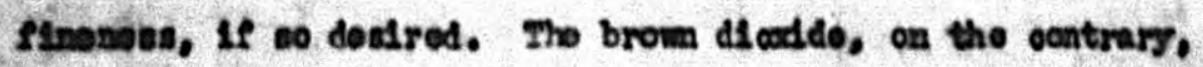
Is a atxtare of oxtromely fine partlalos nixed togother with wory seah laseor partiolos wioh aro not solsd throughout but are in

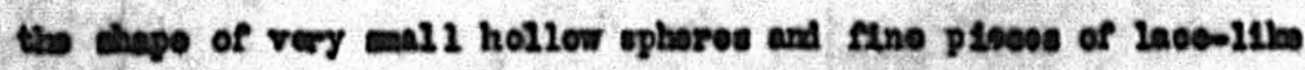

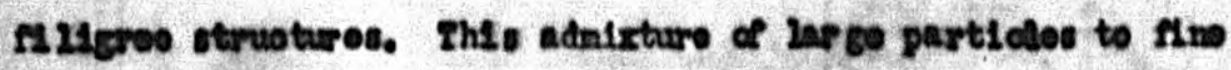
partlolos ha a a very dofinito offoot on Ayrtinor oporations and on the resul to obtal ned. During the reduotion of thes brom dioxide

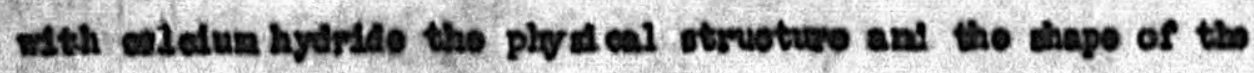
partsoles is not olanged. Tho reduoed pendored intal oeralots of parthoies of the thes shape as in tho welde, that 10, It conalate of partiolos and an approolablo pereentage of the above mentlomed

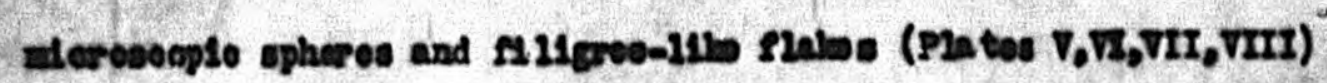




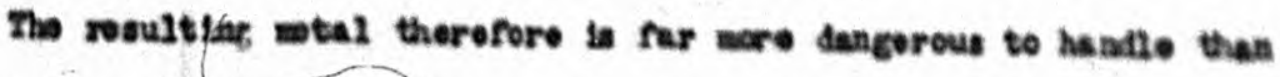
that produose from oulde, oomisting of pirtieles of unifore sise.

- The apparent denalty of the notalise powder protuced troa

the brown dloxide is lose than that produeed mow the blask axdde. Mrthernore, the pressing of the poufer oontaining velero-

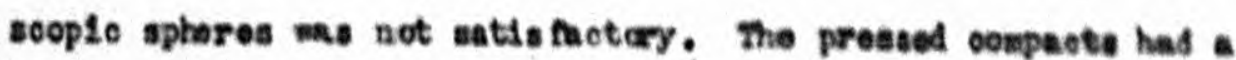
vory muoh lener denedty, often as lom as 2s. The products on of elntered blocke wat a torpornry expedient and allowed our seleb-

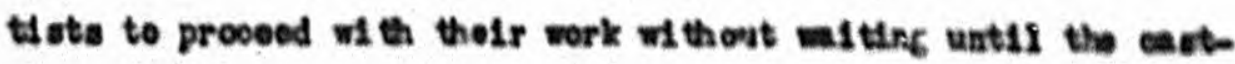
Ins mothod wa per rootod (3). The proasing of the compeots wat diseontinued as soon as Professor Oilpean mocoeded in bringlas hlo mothod of freit on and pouring and oasting in vacuras to tho doetrod docroe of persooti on.

The totial anciount of prossed ant alnterod oubes produeed curlng the tranalti on perlod was 3,060 pounds. Thl metal was alppod to Mrdoago lotallurgloal Laboratory.

v. Roduotien of Brom Dloodde

Tho reduotion to motnl of the brom dicatde by the ealofie

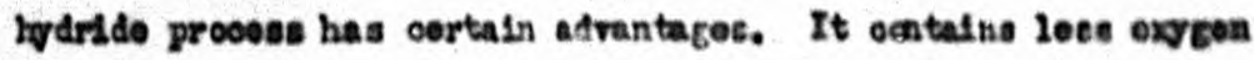
and, thoroforo, Lavolvos a sonouthat amal ler anount of oalofun hydr1del the differonoe is not very great and does not afroet atorializy tho oost of rocuotion. In Inportant advantige, homover, Is the mot that the reaction was proceeding mueh nore guiotis wh that a sudden ovolution of hoat as in tho oase of tho black oxdep.

Tho desaventage of uning the brom dioxide is that the revilting porder is not unlform. It oonalete of a ndxyure of almato paptioles of I0pe than eno mlovon in diarotor, a sertos of eolla partielea of largor dimensions and vory lareo partioleo 
In the rem of halle ephores.

Tho leaching of such aterial wae oomplox problen ofnoc the oend Itiens had to bo regulated to leach quid olky and whtheut

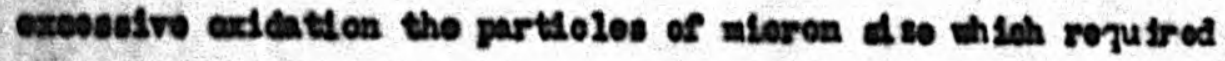
caly a chert thew. The lar cor peotsolos, ourrounded to larger

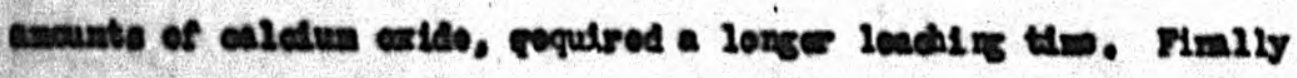
tho halles ephores ocild not be loached ofsootivoly at all in a

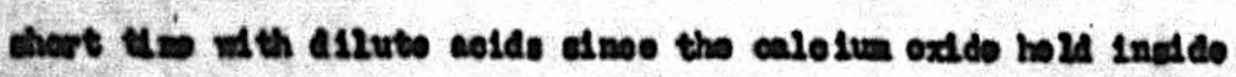
of the hollea ephere wae noro or $20 s e$ proteoted mon tho actien

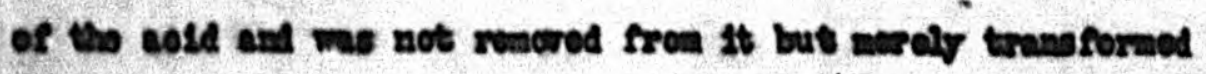

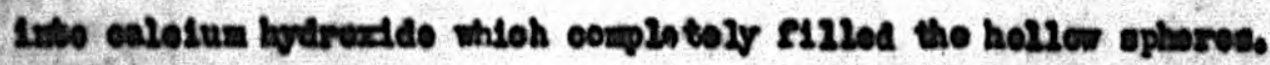

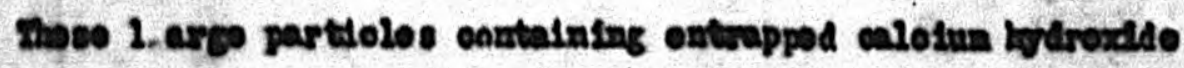
could not be dried thoroughly and rotainod tho noloture for ecreral

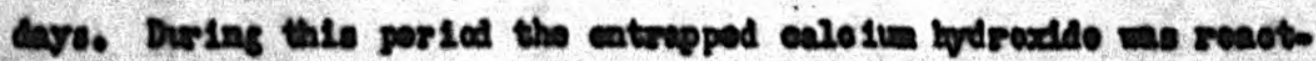

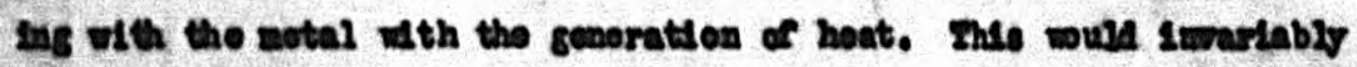

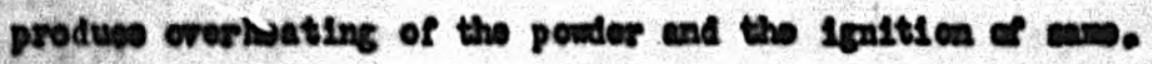

Ino leaching oporation wae rogulated to bo multablo sor the

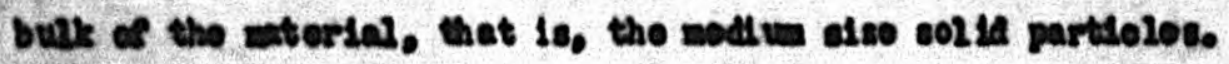

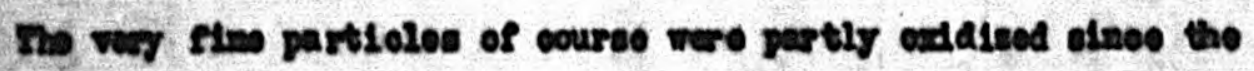
thes was too loase, and ther had to bo eoparated of decantation,

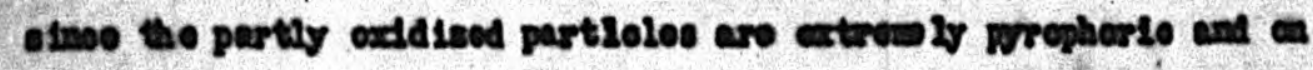

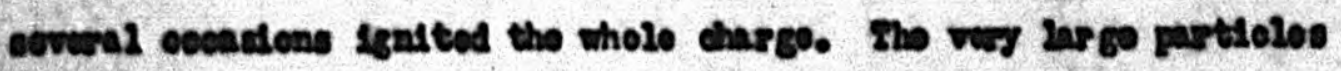

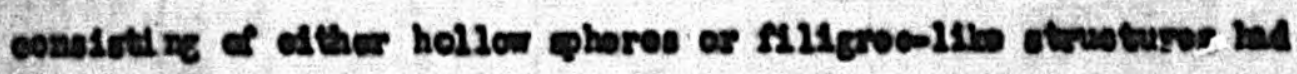
to be eoparated by ecreoning the wot perilor. The pereontage of this

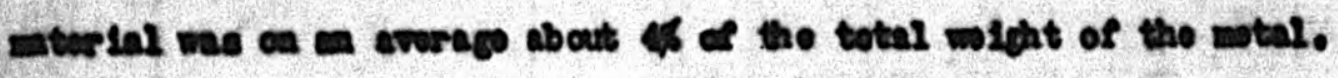
It ceild not bo mited and me topo dangerous to be loft otanding in ats and therostere had to bo burnod to black ocldo and nont for ro-

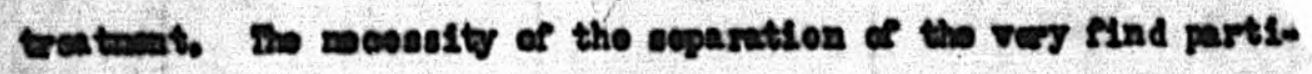

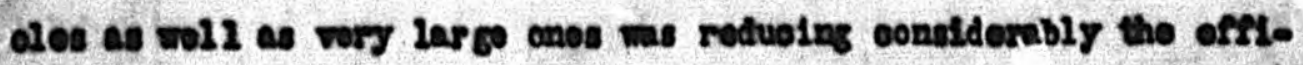
eleng of the preosese. 
In conolusion it ming be otaced that the puriflod brown dioxide from a certaln polist of vion was rore out tablo ros recheo tion by calolus hydride then tho bleck ouddo, yot its ues involved far greater denger in handing and dus to tho zoesenty of discard-

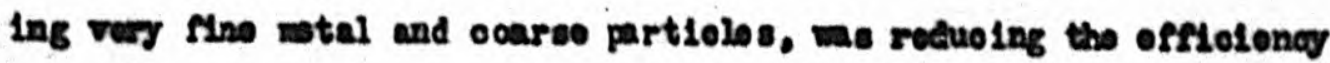
very constdorably.

\section{Dint1lintion of Calclue}

Cul otua hydrldo produced from dist1liod calolun was used erolusively for the roduction of the brom dioxddo since the erute

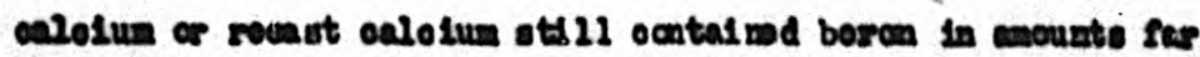

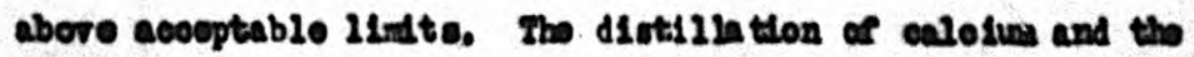
predustlen of puro hydride was carriod out ac sol20we.

Crule onlo tur motel to tho ancunt of an average 60 1bo. wa filaced in tho botton of an iron oylinder as chom on Plato Ks, tho Gilnor wa thon pisoed in tho nichrom rotort. Th lowes pert of this rotort was pliced In an 012-PInefi furnoo and hastad to a tosporature above the molting point of calofum. The rotect was

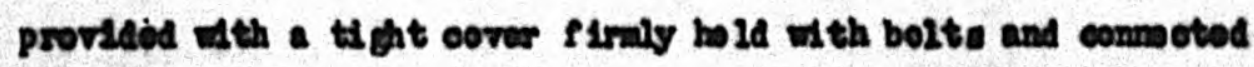

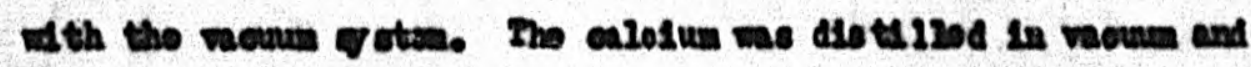
De cealonging in the sorn of a ring in the uppor part of the

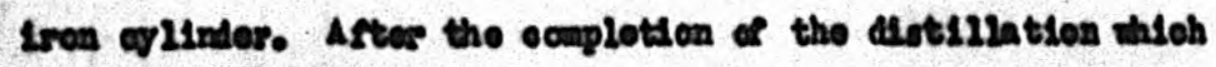

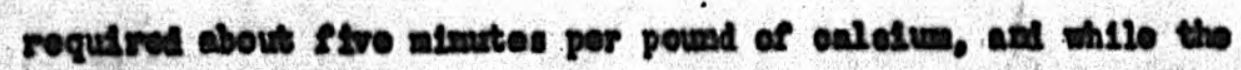

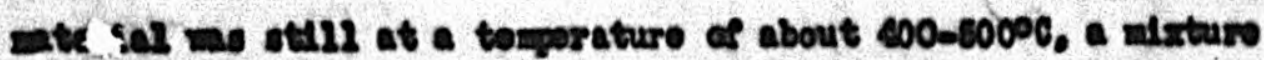

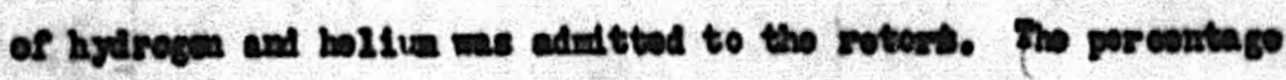

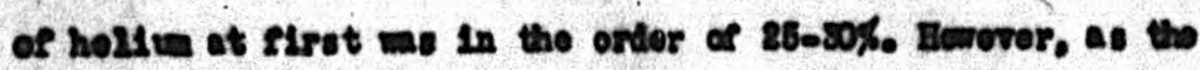
sldy of the eporatere Inoreaced the pereontage of hollu was res duced to $20 \%$ and oven $2 \%$. 
Fhle eopesation of resy Imo partiolos wa deno ea

follewe. Tho leaching drua in wish tho treatmost of pendored

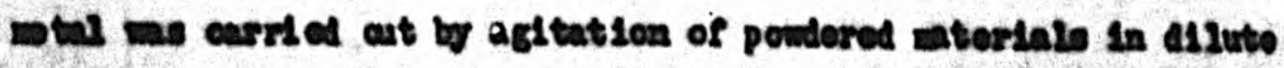

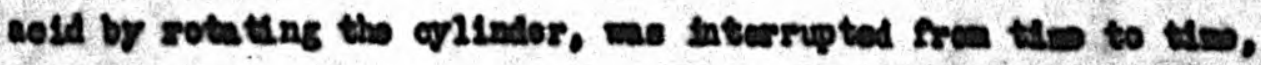

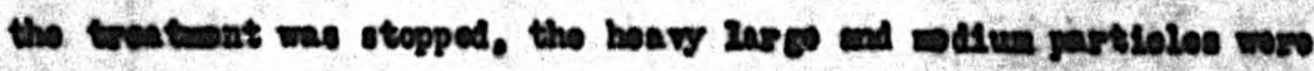

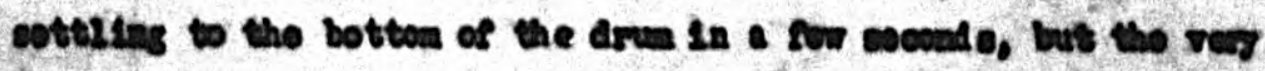

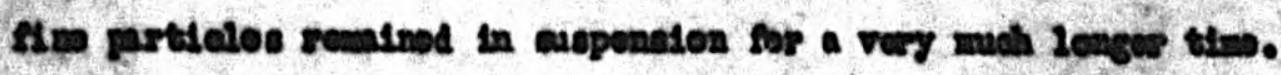

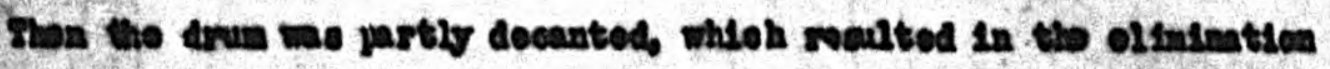
os atw partsoles. Thlo altornato aglatson end.docantatton wa

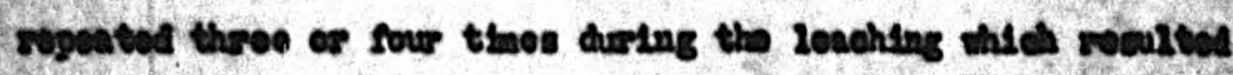
In the olidination of very fim partalos thich were on of the eauses of troublo. The rery heary oeveres partiolos wese

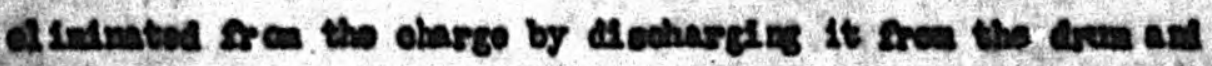

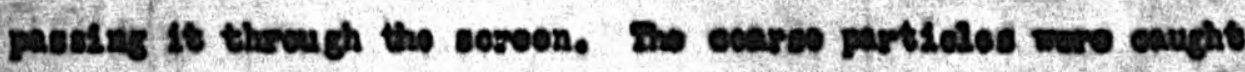

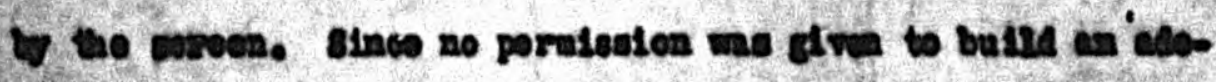

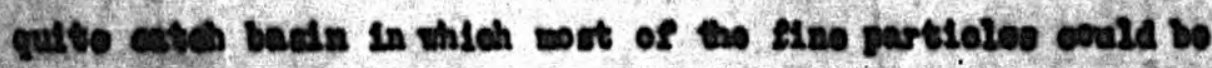

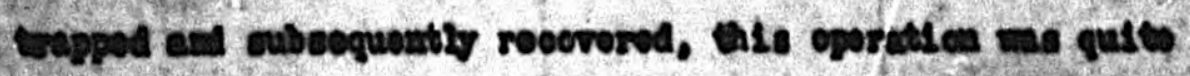

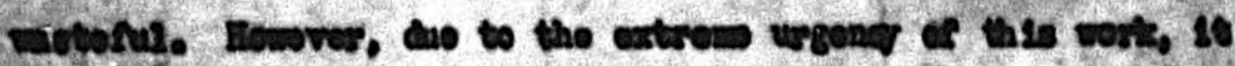
led tó do coer bed a.

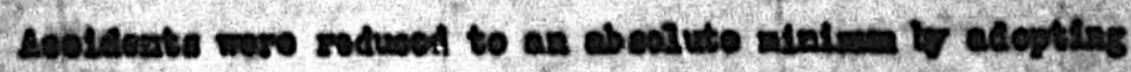
tho techale of eeparntica of wory stino and vory laseo garticlon

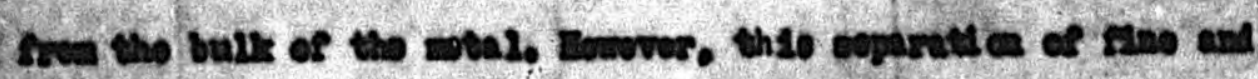
coares partides cataned a 2008 of abeat coj of wital. Iloot

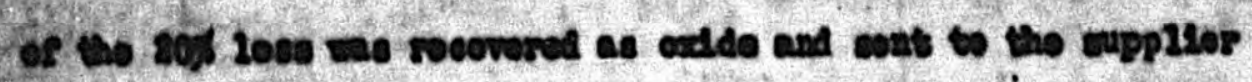

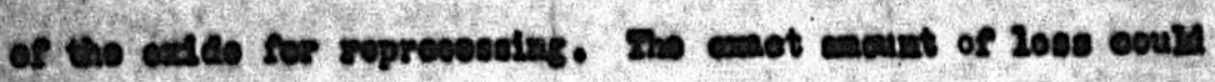

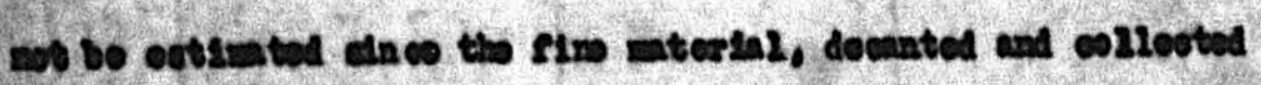

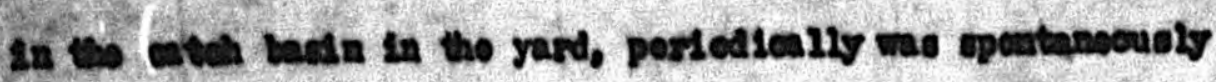
seasosins. 
Hallua was andxod to hodrogen to elow dow tho reactl on,

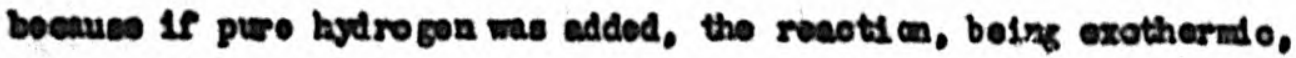
wa proceoding too rapidly with the rosult that the produced al.

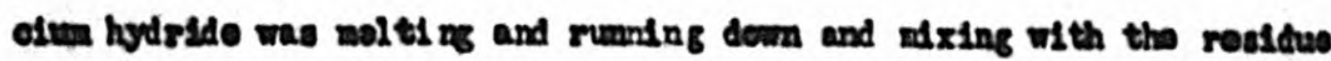

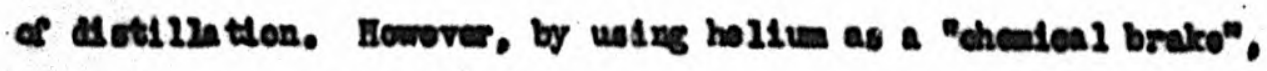

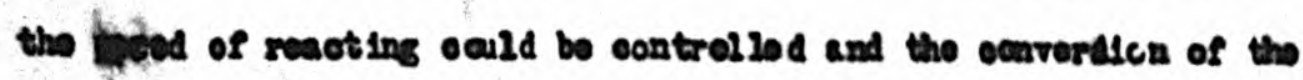

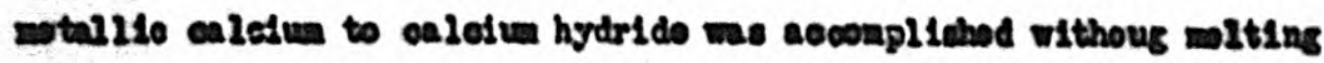
cam. It should be mentiened that inaldo of tho iron oylinder it

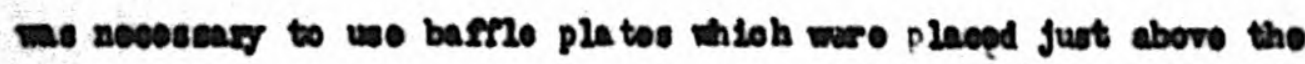

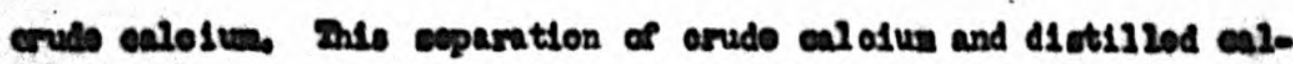

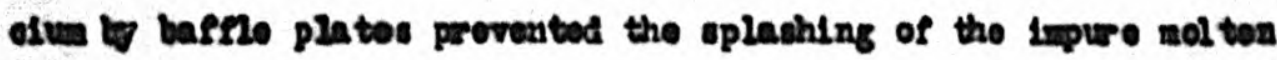
enlole and therosere tho ocotanination of the distillod prefuet.

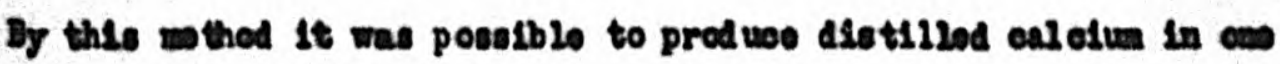
operation and ocenvert it into calo iun hydride.

Tho purity of the oal olum hydrido produned to this wothed

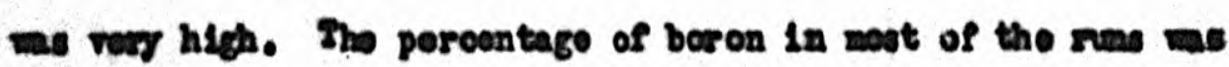
loes than hale of on part por nillsion.

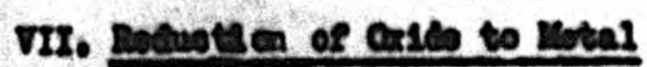

Tho purs diotiliod culolus hodride was ronoved from tho uppor part of tho Iron wilnders to seans of a cold in 1eol, an

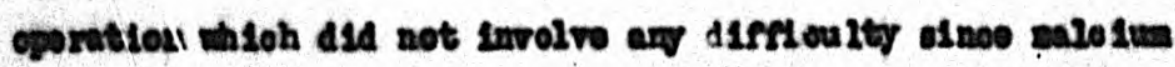

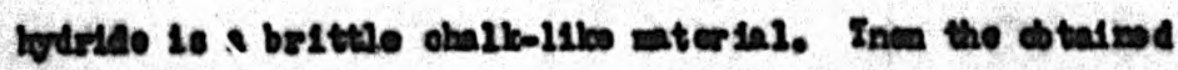

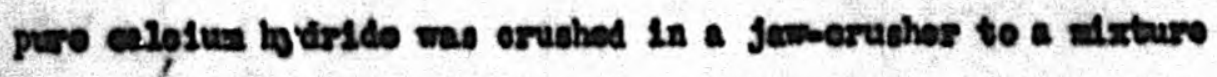

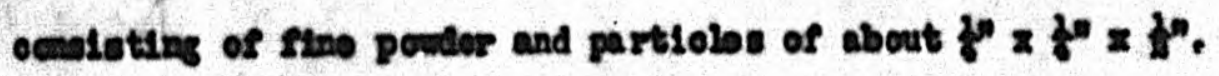

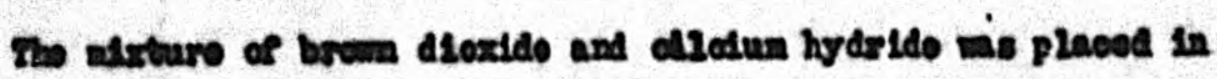

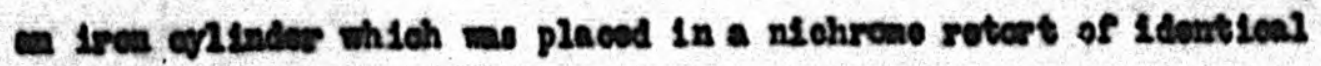
coeder es theeo need for ditil Ilation, (Boo Plato $X$ ) 


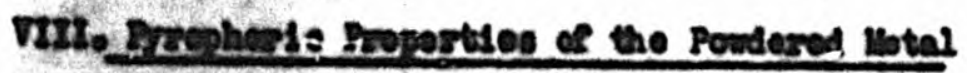

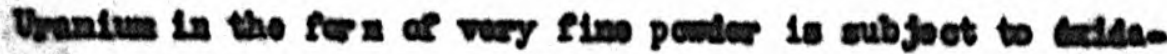

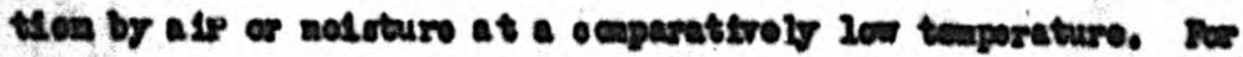

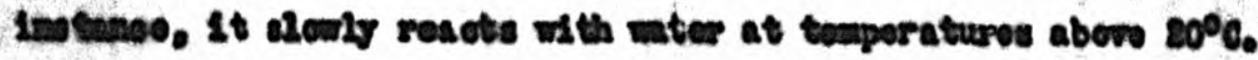

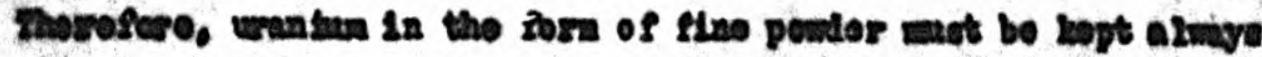

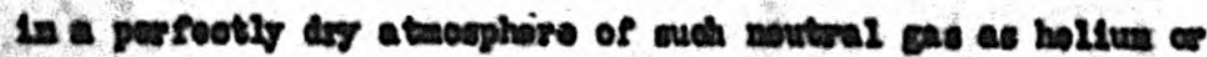
argen.

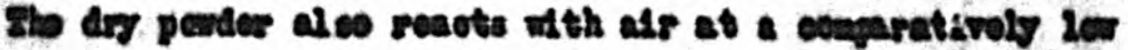

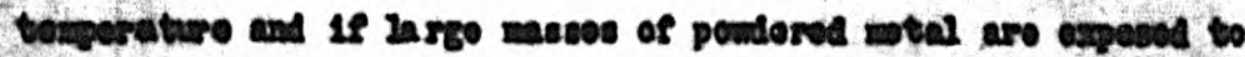

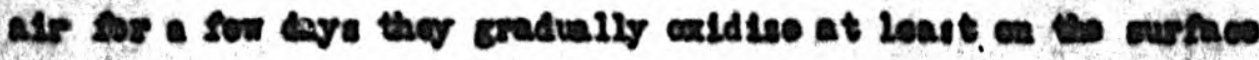

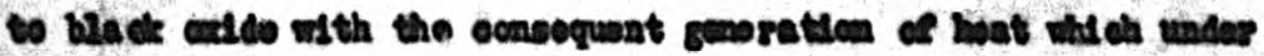

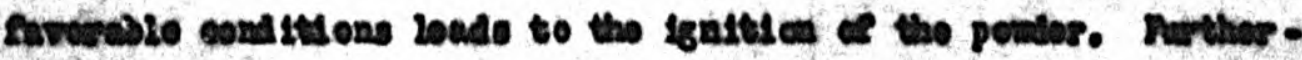

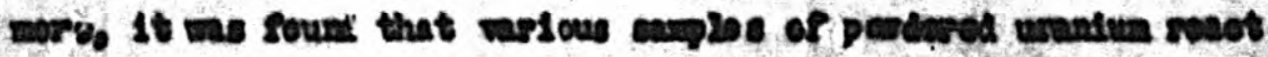

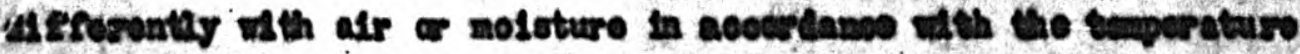
at asch ther wow produced fren tho ad

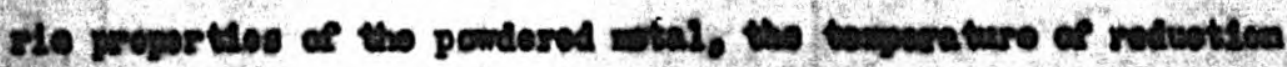

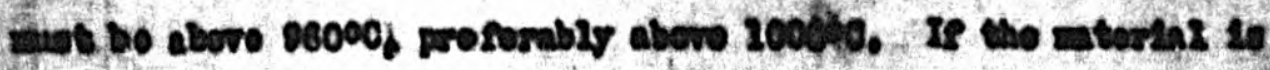

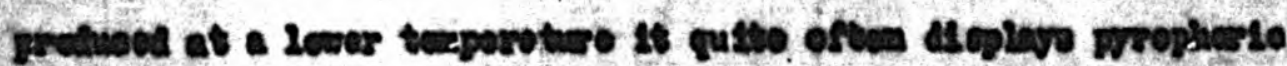

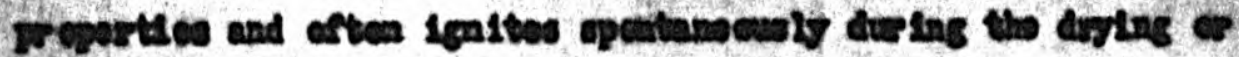
peciling operatilowe.

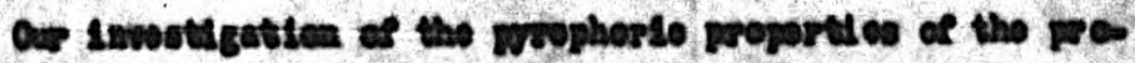

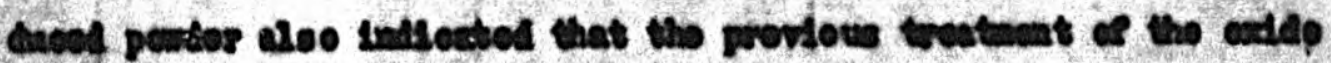

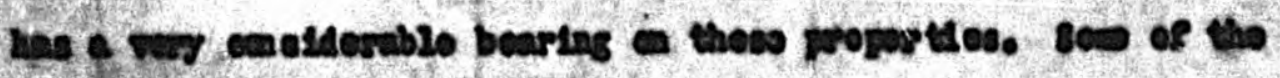

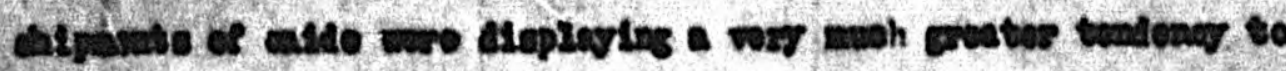

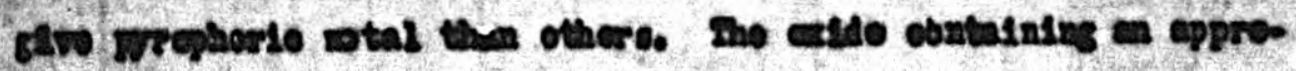

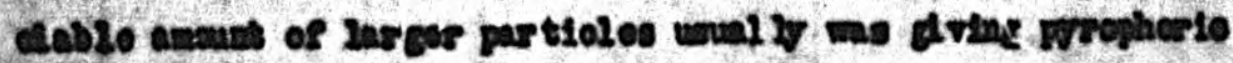

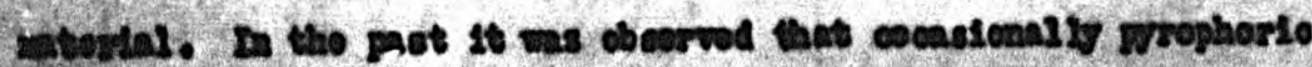

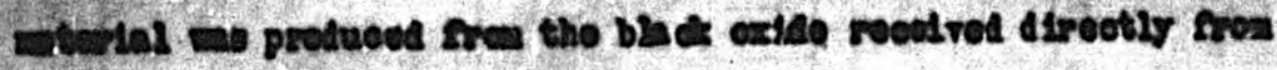


Canda. Zot aines that oxdlo was of very much finor grain oleo,

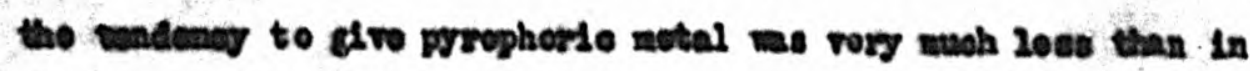
the enes of tho brom diealdo.

Ir. Yeasents:

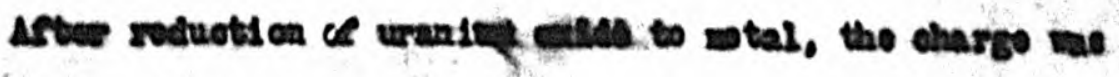

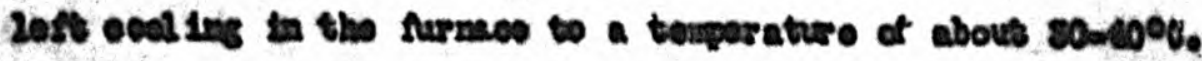

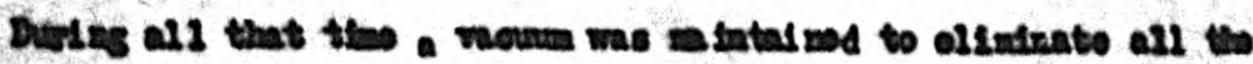

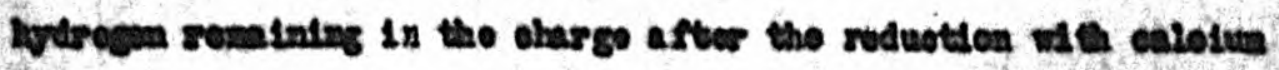

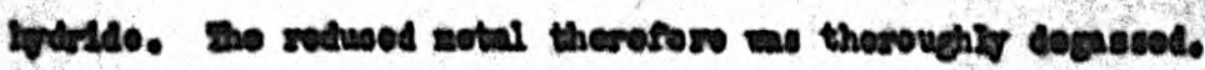

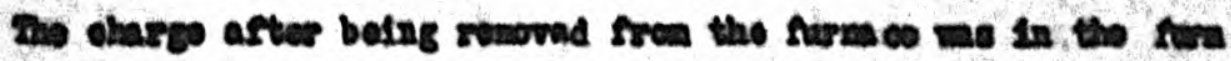
of a elatered olinkes and had to bo renoved fron tho ison ollinder

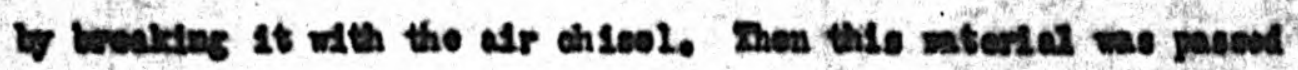

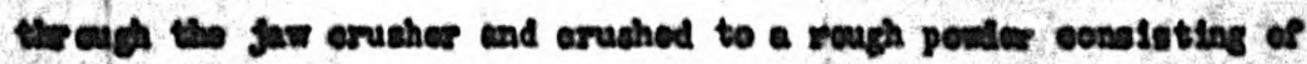

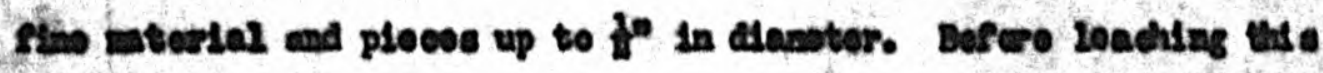

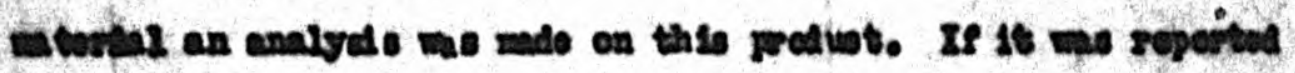

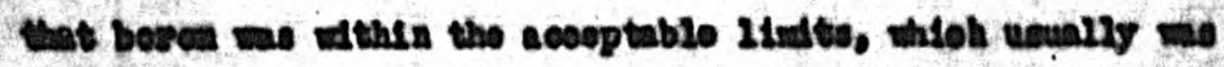

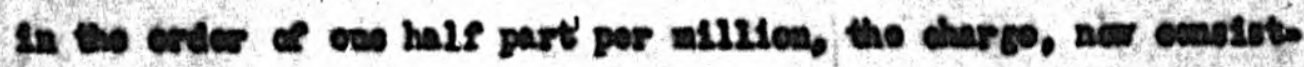

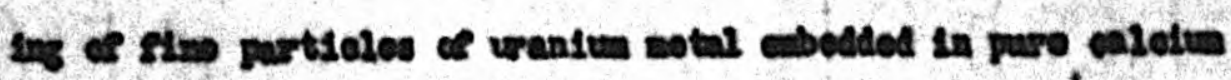

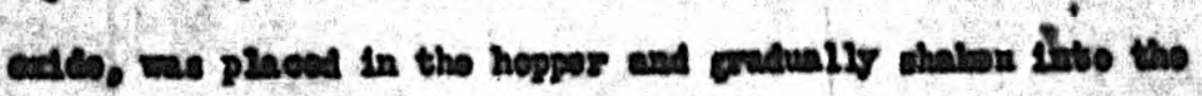

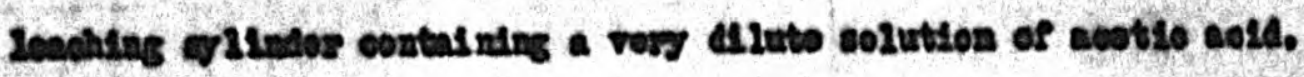
(Coo Nhes axt)

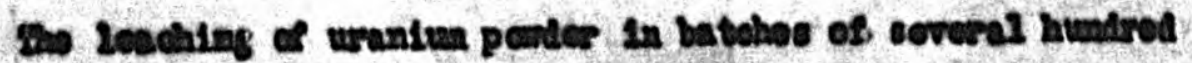

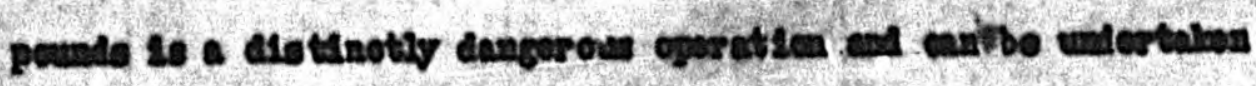

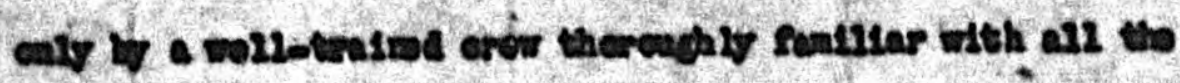
chisus os eath an oporation.

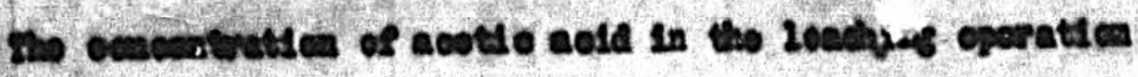

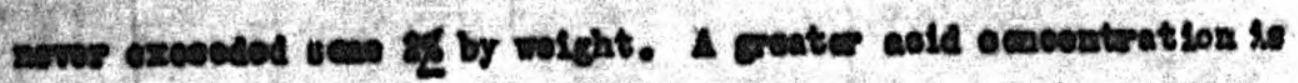

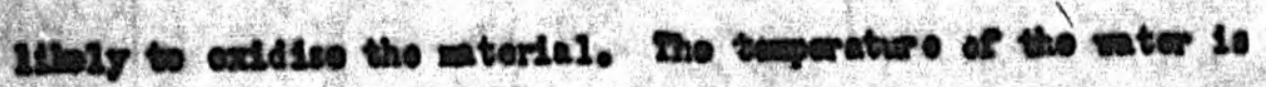

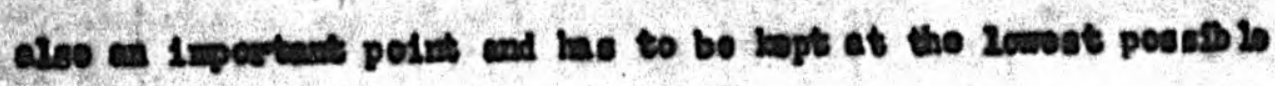


IImit and chould never bo allowed to rico abovo 850C. A constant Vigllares of the teaperatures in tho looohing tanke is a primary consideration for the safoty of the operat ion.

x. Derying

In wot uranila powder, aftor thorough reching on tho ecereon Whth flitored oold nator, was remored to a dry ing roon whose aftere opreading In a very thin layor on mtell10 trave it wes plaoed in the drying ovena provided with a ocntinuous ofreulati on of dy nitrogen, tho dry nitrogen was pasoling over the our fhen of tho

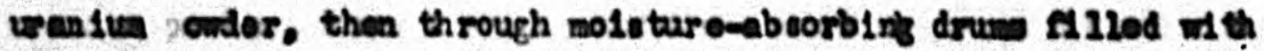

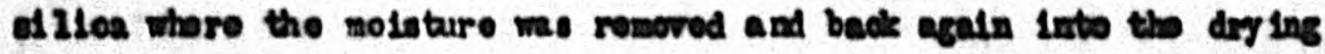

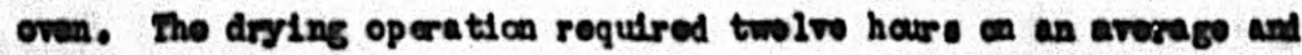
me ounduoted at nighttino, Every chargo, thoroforo, wa dried by the sollowing merning and was ready to bo cent to tho foumdry for alting.

The storage of pondored uranium was scuid poselblo at low

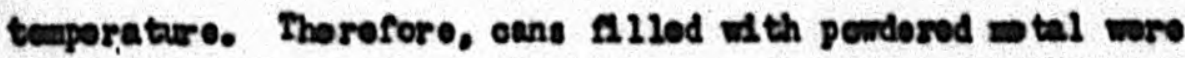
otered in opocial refrigoretore and oooled to a tomporature of $-26^{\circ} 0$ untal ouch tim an the wore renoved to the furrace room. for rewiting.

xI. Isting

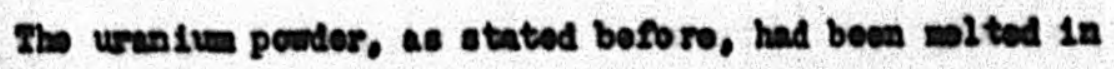

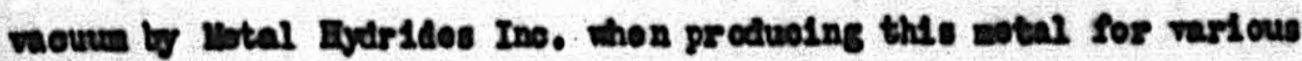
2aberator 10e aineo 1986. Hewerer, the mitting and canting of the o nteorlal In large quantil t10e roquires a diffornat tochnile. Tho problew was colveld by a group of sel enth ote working with Profeseor

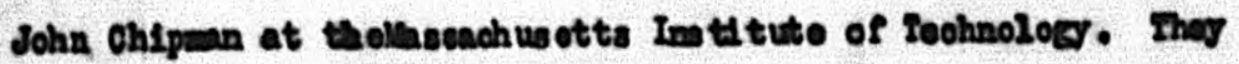
dovised a wothod of cheing uranilum porder In hl fol frequonoy surneces 
In eraphito oruos' 10u. Artor the dovolopiant of this withed of fusion and casting at the laseachusotts Inatitute of Foohnolog a epootal coundry was oquippod at ustal Bydrid os Ino. In Bovorly. whore perdored matorial was mitod at tho rato of about ons ton por dey.

Due to an extrenoly olow dollvery of tho ordored machinom. changes in epoulfieations, and ras matorials, the rogular preduotion we dolared unt12 the ond of the ounerer of 1942. Herrovor, by the

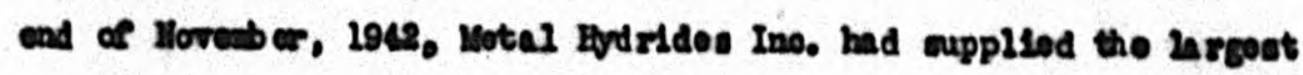
part of tho wotal which went Into the conetruotion at the Crienge

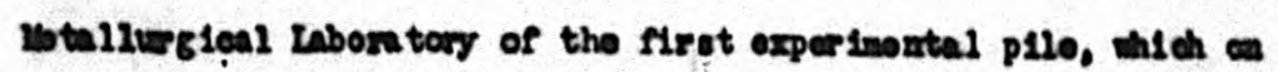
Decentor 2, 2042, as roperted in the surth ropert, was put in oporation and dosinitoly demenateratod the exdintonos of a ohain reect10 n. $_{0}$

III. Conolusiang

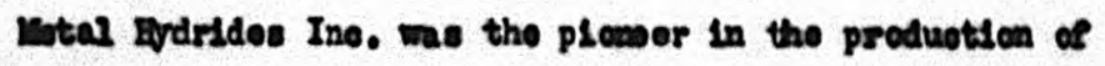

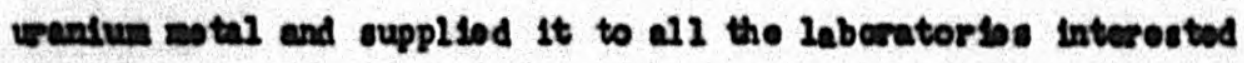
In thile recearch before othor wo thode sor its produotion wore devcloped. Tho conditt one with regard to the analyele, phyaleal fere or guantitlos have been changing, as In overy roecareh projpot,

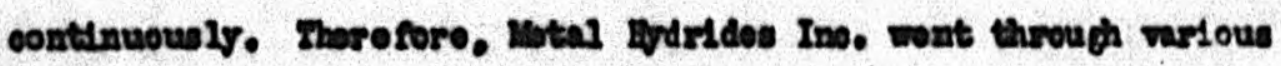
otages of produotlen of this moteal as requosted by the intorveted partilos.

At Elpot tho motal was produced in mall ointored diseo about 2" In diamotor. Then it was produced in exall fuesd ingoto of

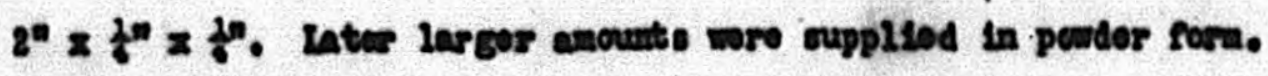

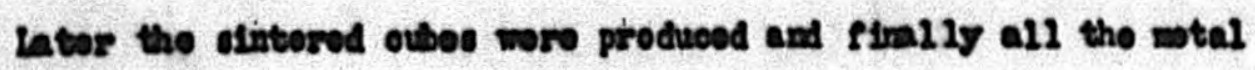

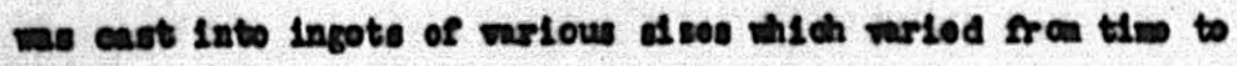


tila from 1" to 6" in dlamatos, end ho ight wae varlod from $2^{\prime \prime}$ to $11^{n}$. The ohoratoel analysis was changed in accordanoo wh the proo groses of the research by the physi oidets oxporibunting with this material. As elrot otandard black ozide inlppod dirootly rros Claneda was used in oxporimats with the mily procaution of olinin-

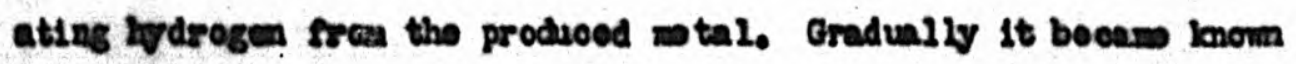
that othor olenente mould be oliminated frem tho motal. Tho lateot

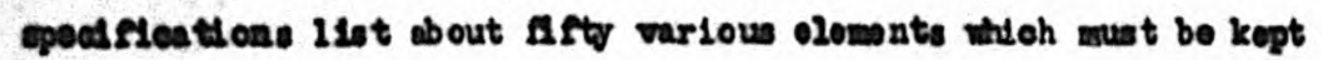

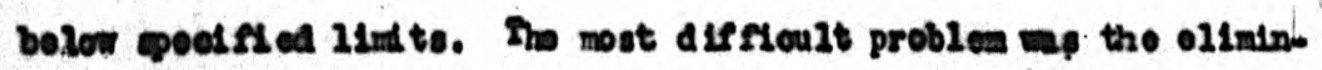
atton of boron wish at firet was as high as 6 parts por million. Oredualis 1 t was roducod to bolow ono part por milllon and meats of

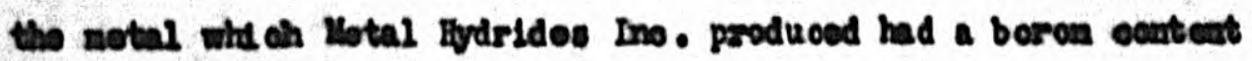
of casty .l to .5 of ons part por milliom. 


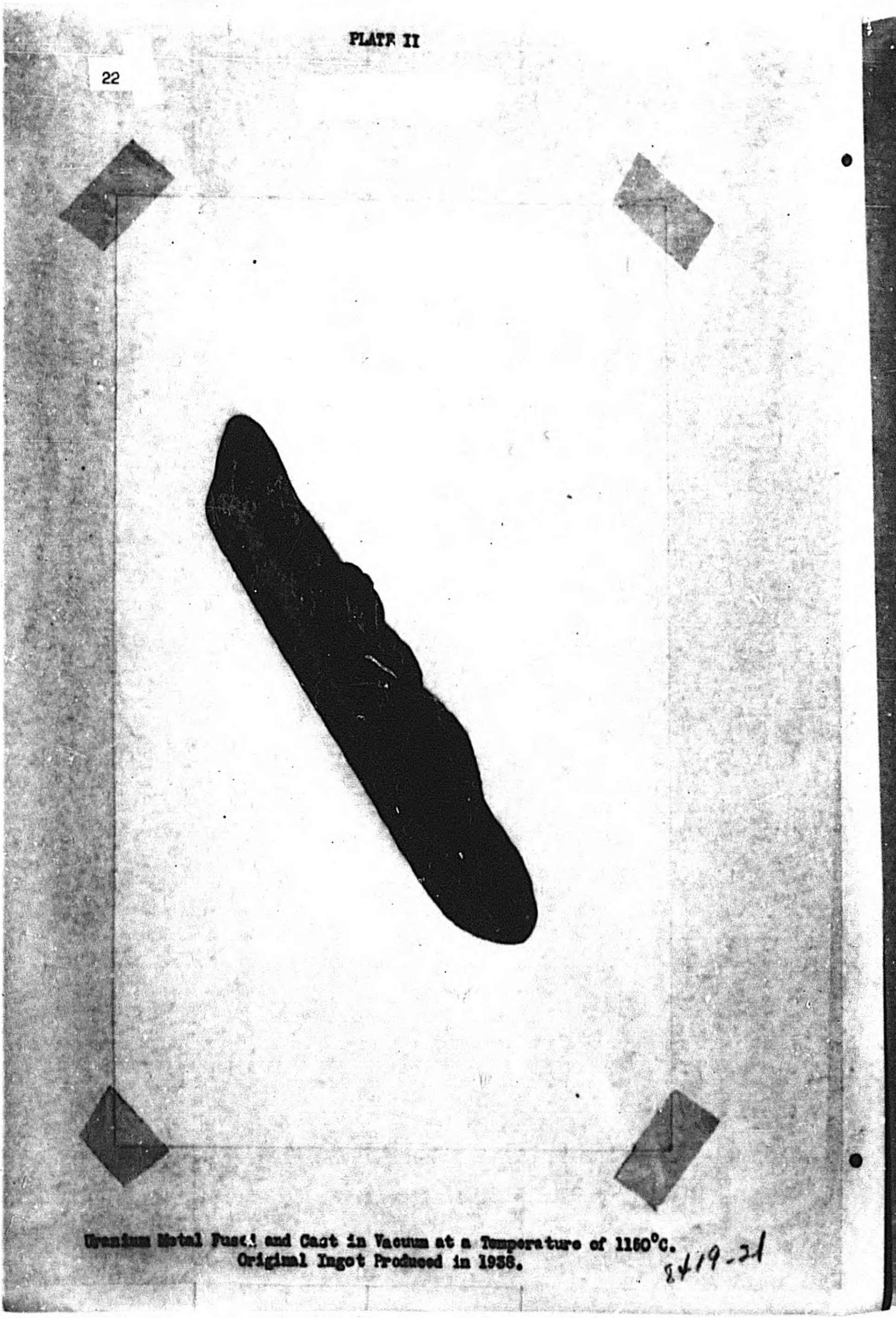




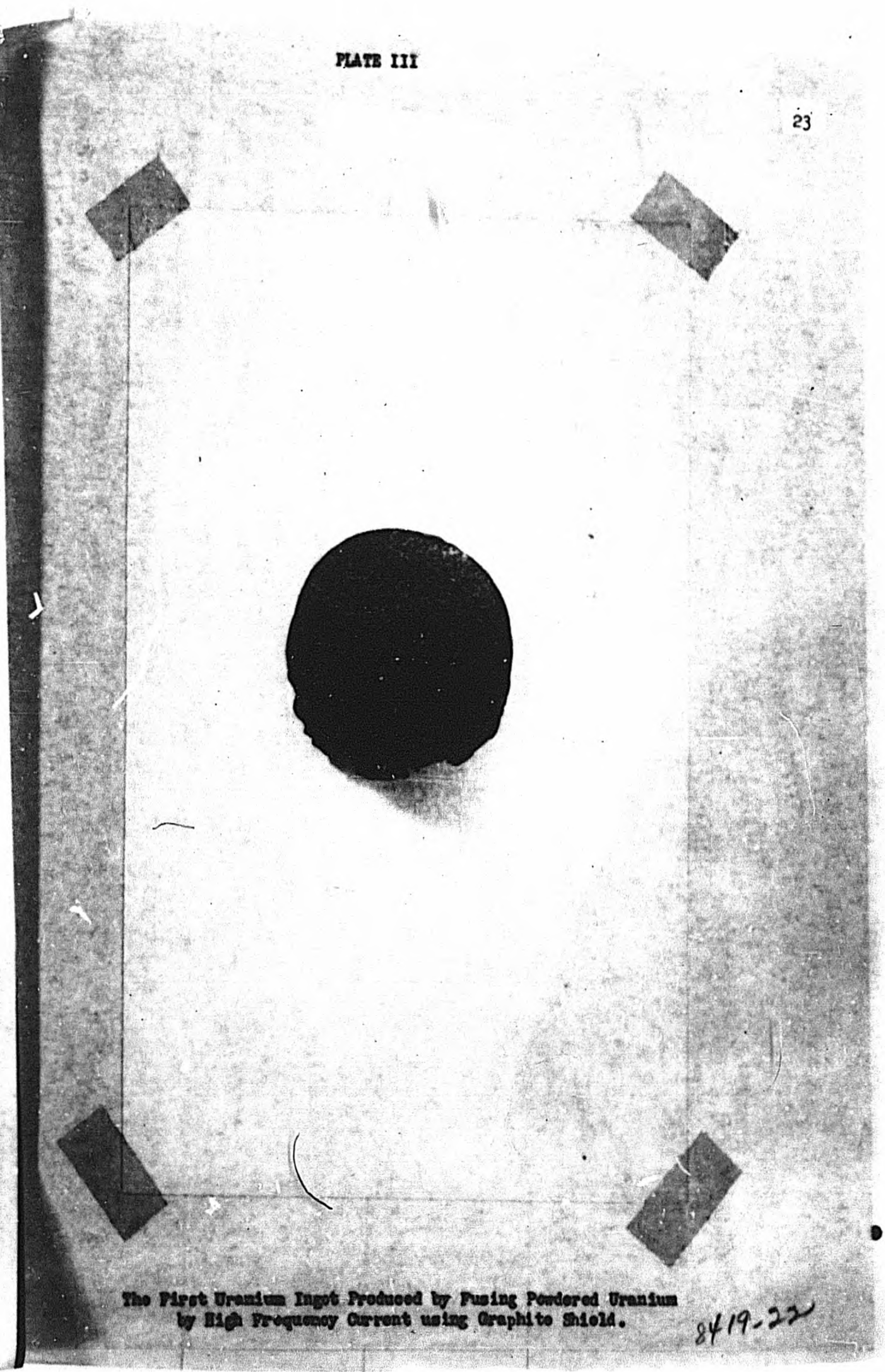




\section{PLATE IV}

241
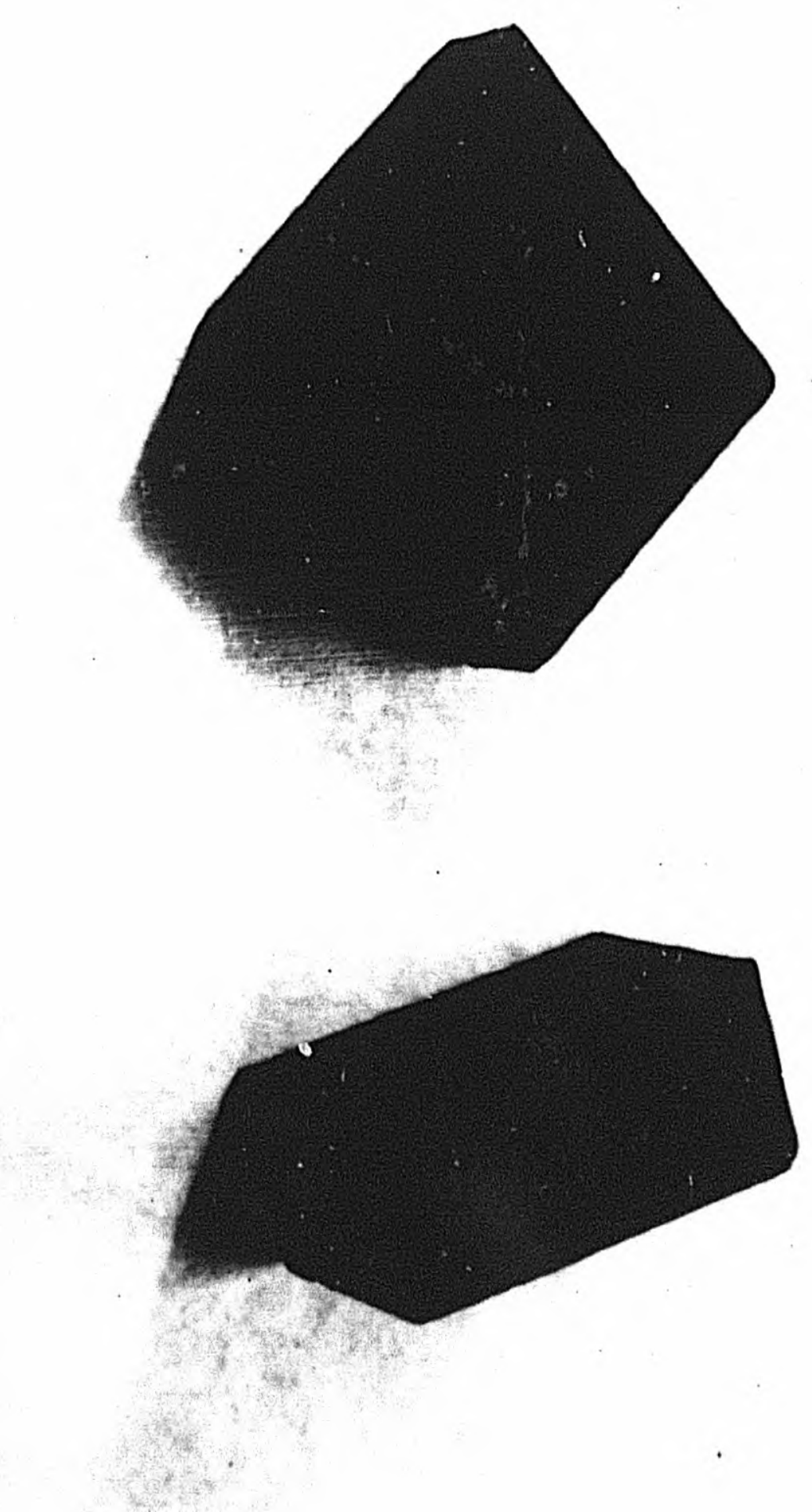


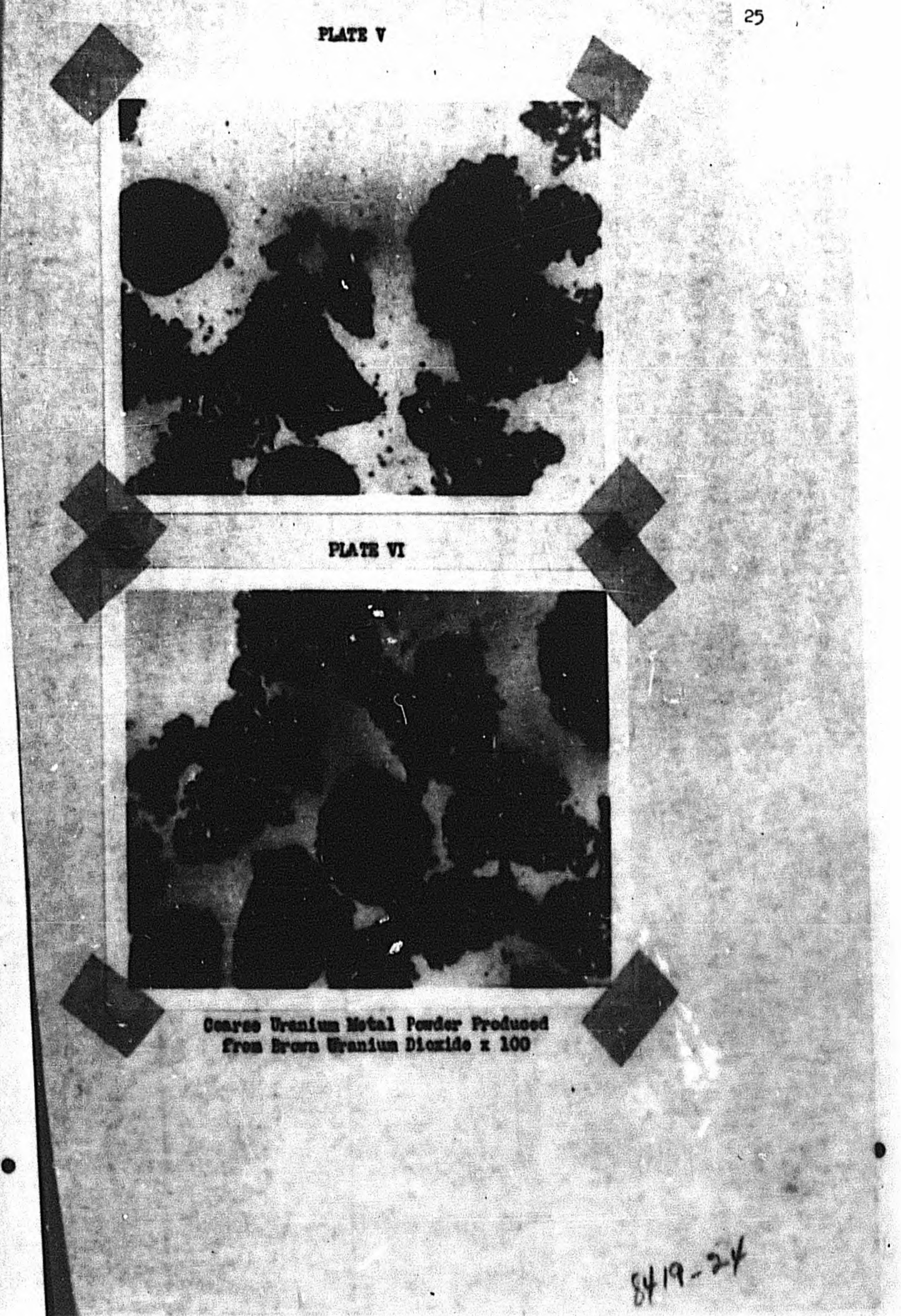




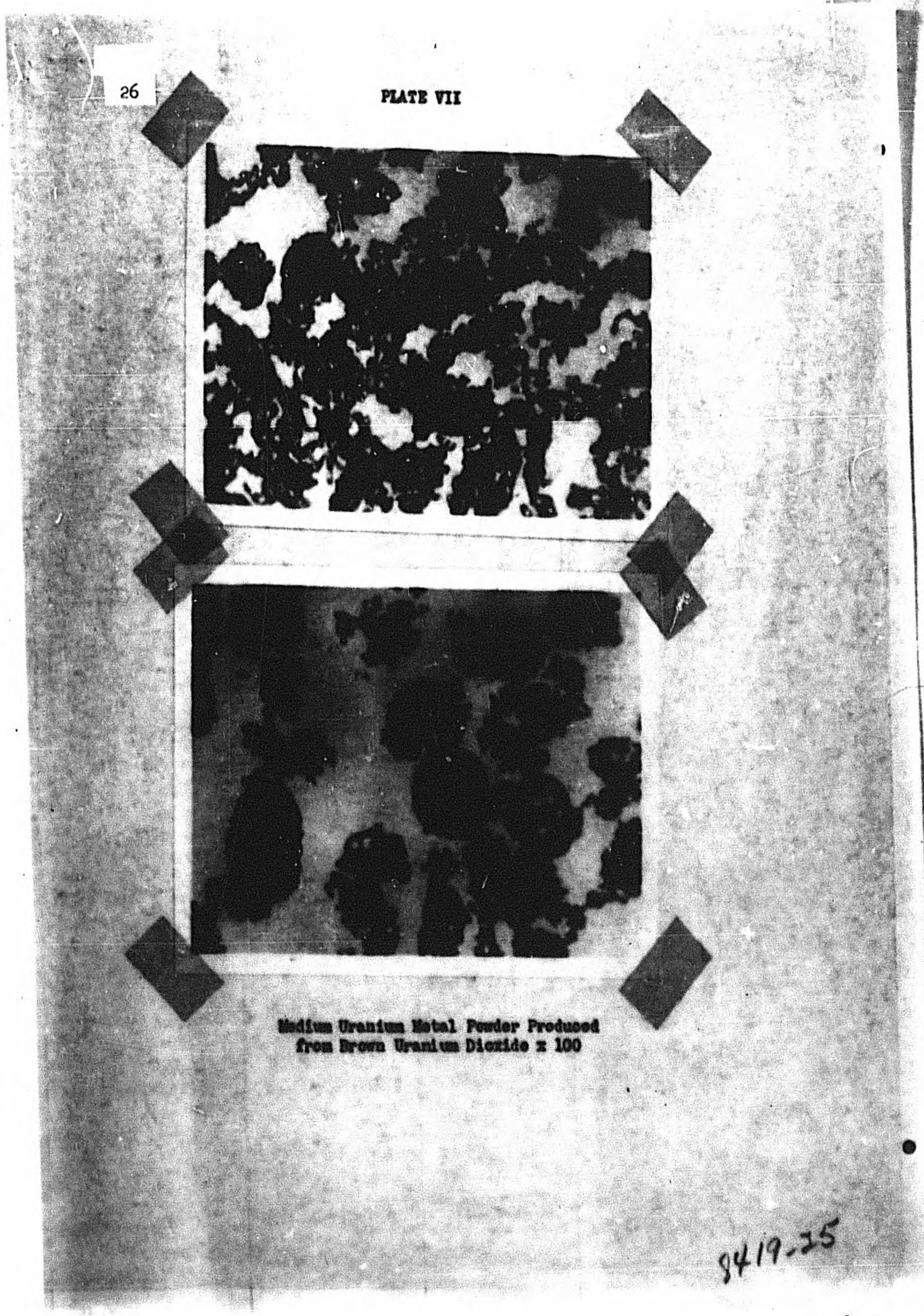


PLATE VIII

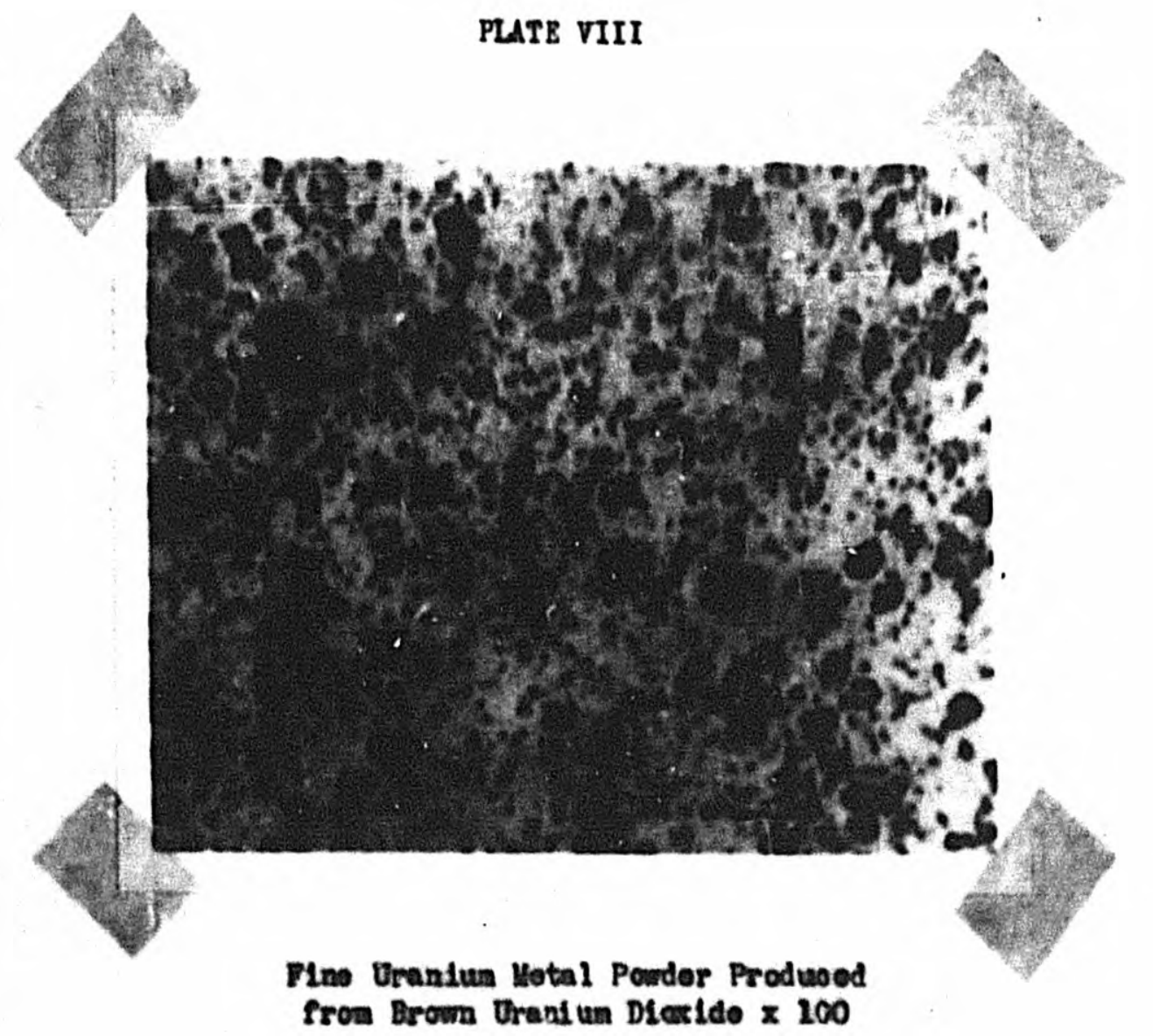

$8+19-26$ 


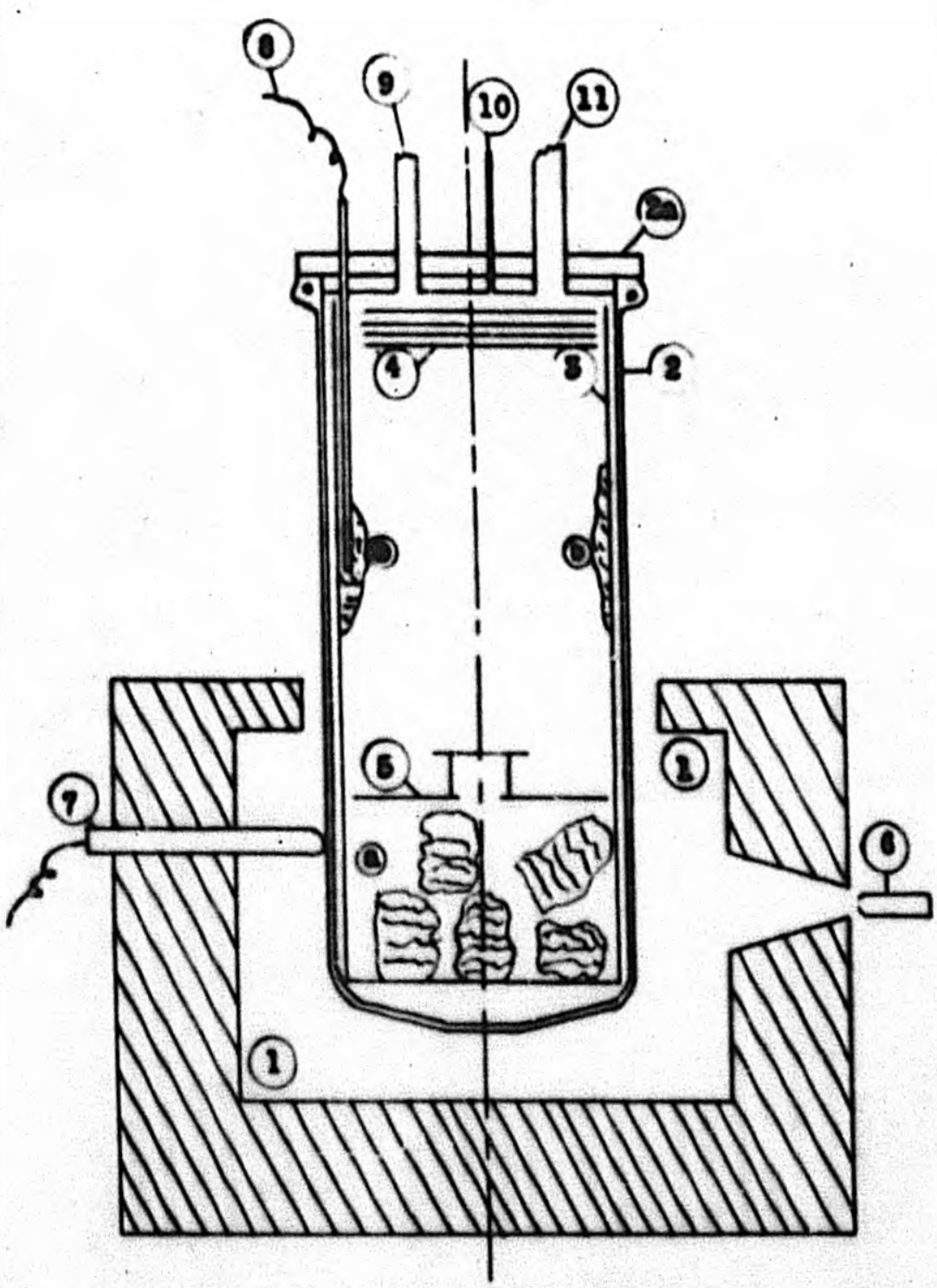

CALCTOM DISTILLITI

a. Calelive Carrote

i. Diotilied calolun.

1. Purnace, briot IIned, oteol sholl

2. Etort (spoeles All

23. Dotort coros (Speela) Alloy)

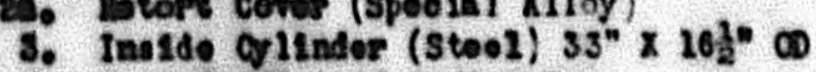

4. Reat Barne and sodium trap

b. Antl-eplash Barfio

6. Burnas (tangontial) oll

7. Thermoeouplo

8. Pyod

D. safoty valve

10. Cause

11. Evdrogen and Reoum Lino

VETAL IMDRIDES INCORPORATTD Bover 1y, Inseachusette Senlos- Approximato 
PLATB X

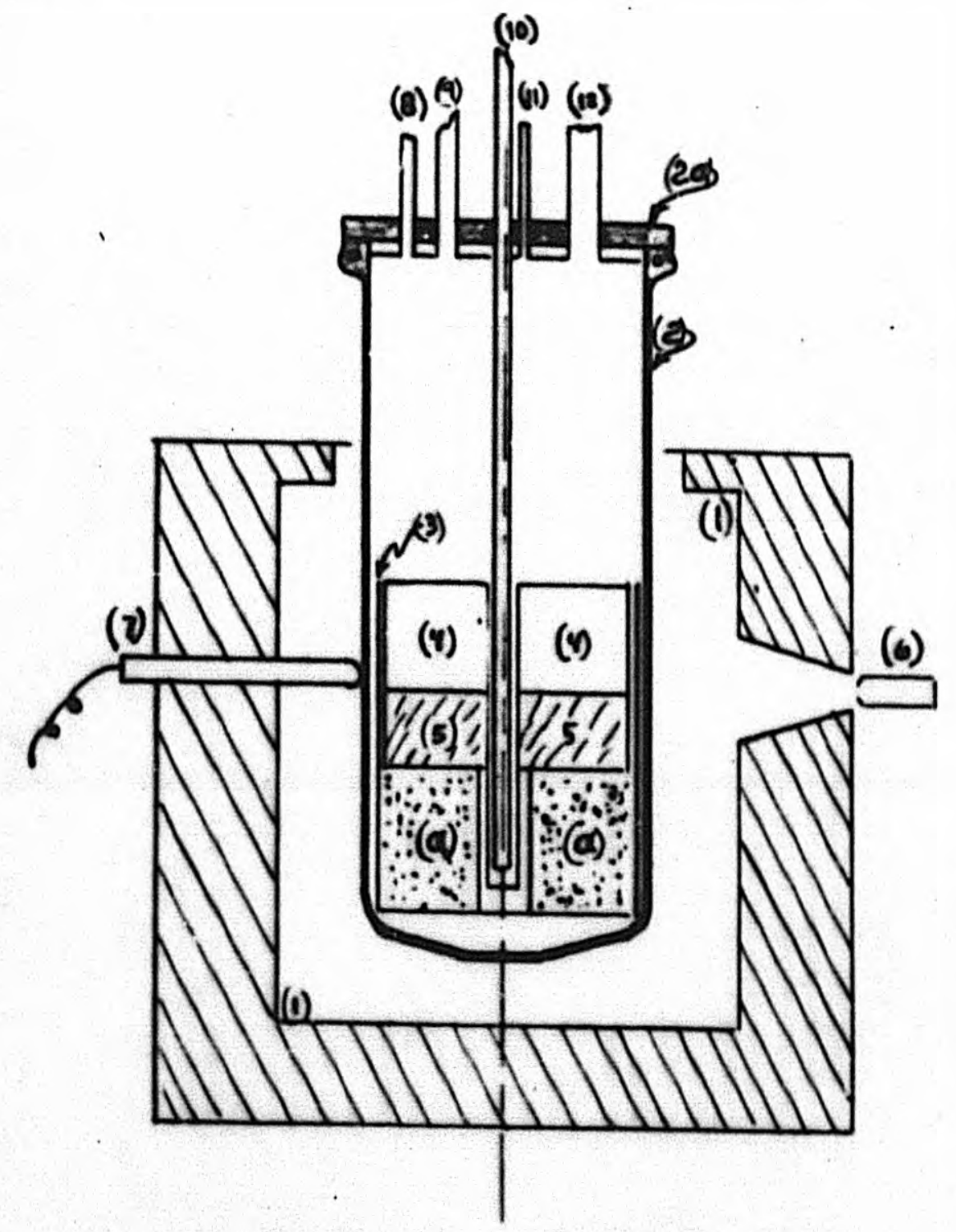

\section{Reduction Furmace}

a) Charge: Tri-Alloy Oxide and Calcium Hydride

i) Furnace: brick lined, sieel shelf

a) Relort: (speciel Allor) $40^{\circ} \times 10 k^{\circ} 00$

a) Relont Cover (- -)

3) Inside Cylinder (steel) $10 \times 16 \mathrm{~g}^{\circ} \mathrm{OB}$

y Had Bafile :fire brich in stest shell

9 Sothem Trap

- Bernor(fangential) ofl ad gess (2)

i) Thermoceutils

Q Uyrogen Rolief

- Soloty Velvo Lino

10) Prod.

i) Cange

Metal Hrorides Incorporated

Beveriy, Massechuselis

Drown approuimaldy to seale

A.C.H.J. July20,1943

D) Mydrogen \& Vecuum Line 


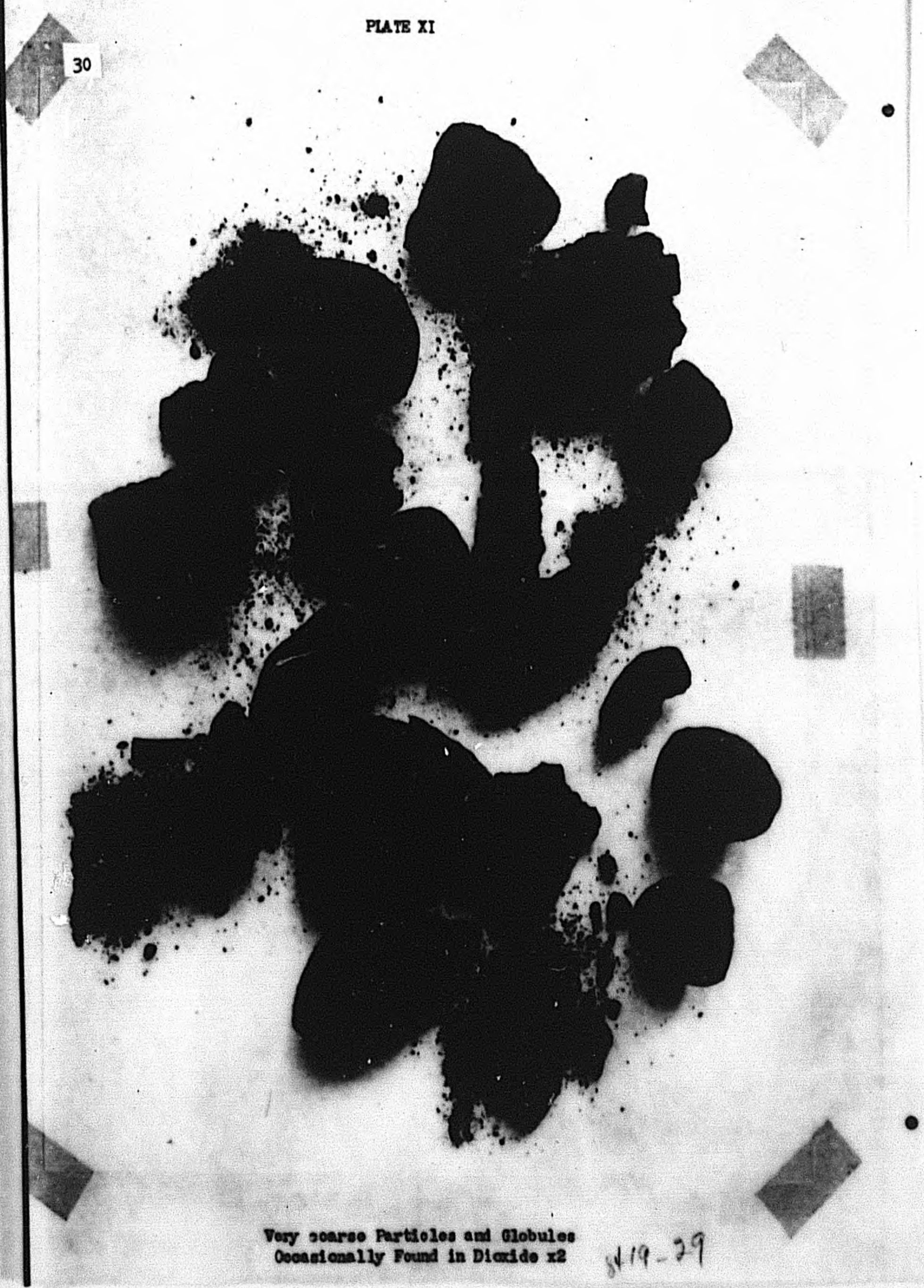



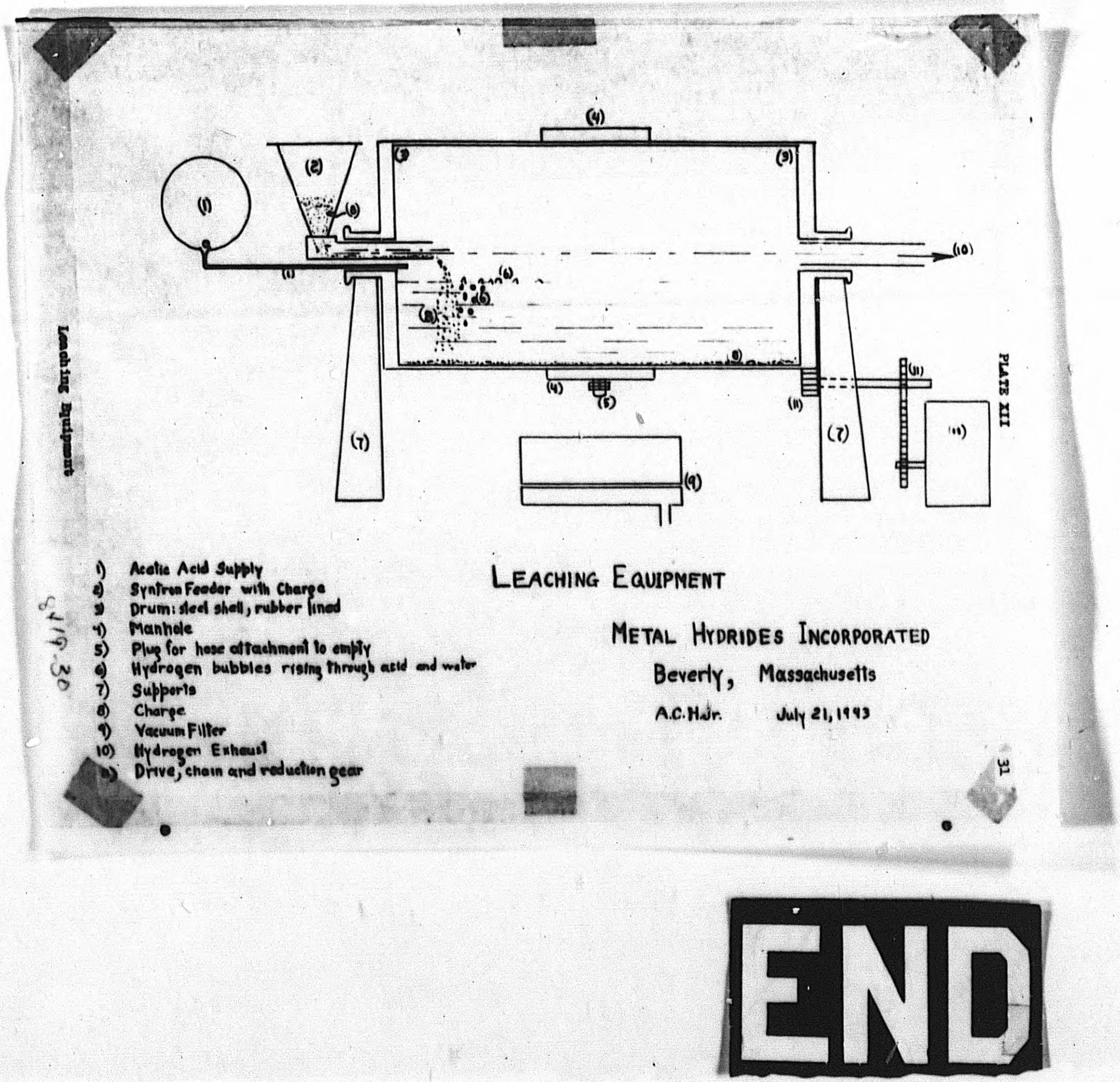